\author{
JAROSEAW CZUBATY \\ Instytut Historyczny Uniwersytetu Warszawskiego
}

\title{
KSIĘSTWO WARSZAWSKIE - PIERWSZE NOWOCZESNE PAŃSTWO POLSKIE?
}

\begin{abstract}
Abstrakt: Artykuł dotyczy kwestii ustroju, instytucji państwowych i życia politycznego Księstwa Warszawskiego (1807-1815). Autor przyjmuje, że głównymi cechami nowoczesnego państwa są: zdolność do skoordynowanej kontroli nad obszarami, które obejmuje oraz do stymulowania nowej integracji kulturowej związanej z rodzącą się świadomością narodową zamieszkującej je zbiorowości. Za istotne kryterium nowoczesności uznaje również gotowość elity rządzącej do podejmowania inicjatyw promujących przemiany cywilizacyjne i zmiany w zakresie struktury społecznej i mentalności.
\end{abstract}

Słowa kluczowe: Księstwo Warszawskie, epoka napoleońska, państwo, tradycja, nowoczesność.
Abstract: The article deals with questions of the political system, state institutions and political life of the Duchy of Warsaw (18071815). The author argues that the main features of the modern state are: the capacity for coordinated control over its territory and for stimulating a new cultural integration resulting from the developing national awareness of the people inhabiting it. They also include the willingness of the ruling elite to undertake initiatives promoting civilizational transformations and changes in the social structure and mentality - recognized as important criteria of modernity.

Keywords: Duchy of Warsaw, Napoleonic era, state, tradition, modernity.

W sześć dni po nadaniu przez Napoleona konstytucji Księstwu Warszawskiemu Dyrektorium Generalne Komisji Rządzącej wydało obwieszczenie zawierające najważniejsze informacje na temat ustroju nowego państwa:

Rodacy! Lubo w ścieśnionych zostajemy granicach, Rządca jednak wielkiej części świata, zajęty jedynie szczęściem ludu, który przez moc oręża swego oswobodził, nadając nam Konstytucję miał na względzie to wszystko, co najmilszem być mogło przodkom naszym [--]. Wolność i Niepodległość 
to było zawsze hasłem naszym, to nam najuroczyściej zapewnił. Naród nasz widzi zwróconą na tron tę krew, do której zawsze tak był przychylny i przywiązany, Dom Saski jest znowu panującą u nas dynastią, a monarcha z cnót swoich uwielbiany ma sobie poruczony los kraju naszego. Język ojców naszych, któryśmy z taką starannością, jak ostatnią narodowego życia iskierkę zachowywali, jest nam na zawsze przywrócony. Rodacy jedynie urzędy obsiądą. Zapewniona opieka dla ludu przypomina nam ulubionych królów Aleksandra i Kazimierza. Wszystkie klasy mieszkańców równych praw, równych swobód używać będą. [--] Wojsko, którego waleczne usiłowania tyle zaszczytu narodowi przyniosły [--] w całkowitym swym składzie utrzymane zostanie. [--] Zapewniony rząd wolny, krew od nas ulubiona na tronie, język naddziadów naszych zachowany, opieka równo do wszystkich klas ludu rozciągnięta, utrzymana sława wojska naszego; oto są nadgrody ofiar i cierpień waszych ${ }^{1}$.

Obwieszczenie miało uspokoić nastroje opinii publicznej, zaniepokojonej pogłoskami na temat rozstrzygnięć w kwestii polskiej, które zapadły podczas rokowań pokojowych w Tylży. Podpisani pod nim Feliks Łubieński i Ignacy Szczurowski, prezes i sekretarz Dyrektorium Generalnego, starali się zręcznie wywiązać z powierzonego im zadania, wyraźnie podkreślając informacje, które mogły zadowolić rodaków, a zarazem dość ogólnikowo sygnalizując te spośród zapisów konstytucji nadanej przez Napoleona Księstwu Warszawskiemu, co do których można było spodziewać się, że spotkają się z chłodnym lub niechętnym przyjęciem. Nie było ich mało. Prawno-ustrojowy system nowego państwa miał znacznie odbiegać od oczekiwań wielu, jeśli nie większości jego mieszkańców zainteresowanych sprawami publicznymi.

System prawno-ustrojowy Księstwa Warszawskiego był przedmiotem licznych rozpraw z zakresu historii ustroju i instytucji, nie ma zatem konieczności, by omawiać go szczegółowo. Warto jednak zwrócić uwage na najważniejsze jego cechy. Nadana przez Napoleona konstytucja czyniła z Księstwa Warszawskiego państwo, w którym władza została skoncentrowana w ręku króla Saksonii Fryderyka Augusta. Zgodnie z formułą: „rząd jest w osobie króla", władca za pośrednictwem podporządkowanej mu, scentralizowanej i obdarzonej szerokimi kompetencjami administracji sprawował pełnię władzy wykonawczej. Posiadał również zdecydowaną przewagę nad dwuizbowym parlamentem, który pozbawiono inicjatywy ustawodawczej i ograniczono swobodę prowadzonych $\mathrm{w}$ nim debat. Nadzwyczajną pozycję monarchy w państwie umacniało dodatkowo

1 Obwieszczenie Dyrektorium Generalnego Komisji Rządzącej z 28 VII 1807 r., „Gazeta Warszawska" 1 VIII 1807, nr 61. 
sprawowane przez niego zwierzchnictwo nad armią, prawo nominowania sędziów czy możliwość „,dopełniania” konstytucji przy pomocy aktów wykonawczych rozwijających i uzupełniających niektóre spośród jej lakonicznych zapisów. W porównaniu z epoką przedrozbiorową zdecydowanie mniejszy wpływ na życie polityczne wywierać miały organy o charakterze samorządowym. Zgodnie z konstytucją rola sejmików i nowo powołanych zgromadzeń gminnych miała sprowadzać się do wyboru posłów i deputowanych do Izby Poselskiej oraz kandydatów na sędziów pokoju, członków rad departamentowych, powiatowych i municypalnych. Te ostatnie miały pełnić funkcje doradczo-kontrolne wobec władz administracyjnych.

Zasadnicze zmiany nastąpiły w sferze statusu prawnego jednostek i całych grup społecznych oraz ich możliwości, choćby ograniczonych, partycypacji w życiu politycznym. Artykuł 4 konstytucji znosił poddaństwo chłopów i wprowadzał zasadę równości wobec prawa. W Izbie Poselskiej obok szlacheckich posłów pojawili się deputowani wybierani na zgromadzeniach gminnych przez nieszlacheckich wyborców spośród kandydatów spełniających wymogi cenzusu wykształcenia, zasług lub majątku. Obowiązującym w Księstwie Warszawskim prawem cywilnym stał się Kodeks Napoleona - nowoczesna kodyfikacja wywodząca się „z ducha Deklaracji z 1789 r., w której zapisane były podstawowe prawa naturalne jednostki: wolności osobistej, równości wobec prawa i nieskrępowanej własności" i uznawana do dziś za "arcydzieło sztuki legislacyjnej swojej epoki”2.

Podobne wzorce prawno-ustrojowe pojawiały się we wszystkich państwach znajdujących się w sferze wpływów cesarza Francuzów. Choć pewne elementy nowego ustroju, jak dwuizbowy parlament z izbą poselską wyłanianą w wyborach bezpośrednich, wyraźnie nawiązywały do polskiej tradycji politycznej, to jednak nadana przez Napoleona konstytucja wprowadzała model państwa będący zaprzeczeniem nie tylko opartej na silnym sejmie demokracji szlacheckiej, ale także porządku trzeciomajowego, który miał zapewnić utrzymanie politycznej równowagi poprzez pogodzenie silnej władzy króla ze znaczącą rolą sejmu. Marceli Handelsman określał system polityczny wprowadzony w Księstwie Warszawskim jako „urządzenie władzy silnej, prawie autorytarnej, prawdziwie monarchicznej z zachowaniem pozorów życia parlamentarnego". Marian Kallas klasyfikował ustrój państwa powołanego do życia w Tylży jako „ograniczoną monarchię konstytucyjną"3.

${ }^{2}$ K. Sójka-Zielińska, Kodeks Napoleona. Historia i współczesność, Warszawa 2008, s. 77, 79.

${ }^{3}$ M. Handelsman, Z dziejów Księstwa Warszawskiego. Geneza Księstwa i jego statutu, w: idem, Studia historyczne, cz. 1, Warszawa 1911, s. 192; M. Kallas, Historia ustroju Polski, Warszawa 2005, s. 199. 
Historycy analizujący system prawo-ustrojowy Księstwa Warszawskiego wskazywali, że choć był on w dużej mierze oparty na wzorcach francuskich, odwoływał się również do tradycji polskiej z czasów przedrozbiorowych oraz wykorzystywał, zwłaszcza w zakresie organizacji administracji, rozwiązania pruskie ${ }^{4}$. Do tych ostatnich sięgano zresztą także wcześniej, w okresie organizacji tymczasowych polskich władz na ziemiach zaboru pruskiego, podporządkowanych powołanej przez Napoleona Komisji Rządzącej5.

${ }^{4}$ Por. np. W. Sobociński, Historia ustroju i prawa Księstwa Warszawskiego, Toruń 1970, s. 125; W. Sobociński, M. Senkowska-Gluck, Księstwo Warszawskie, w: Historia państwa i prawa Polski, t. 3: Od rozbiorów do uwłaszczenia, red. J. Bardach, M. Senkowska-Gluck, Warszawa 1981, s. 99; podobne oceny w: J.A. Goclon, „Polska na królu pruskim zdobyta”. Ustrój, administracja i sądownictwo doby Komisji Rządzącej w 1807 r., Wrocław 1999, s. 177-178; P. Cichoń, Rozwój myśli administracyjnej w Księstwie Warszawskim 1807-1815, Kraków 2006, s. 18-19. Na wpływ wzorców francuskich zwraca uwagę Michał Gałędek, Miejsce resortu spraw wewnętrznych w administracji Księstwa Warszawskiego, „Krakowskie Studia z Historii Państwa i Prawa" 6 (4), 2013, s. 407.

${ }^{5}$ J.A. Goclon, op. cit., s. 177-181. W jednej ze swych prac Dariusz Łukasiewicz uznał przedstawioną przez mnie (Księstwo Warszawskie 1807-1815, Warszawa 2011) charakterystykę rządów pruskich do 1806 r. i ocenę ich wpływu na sytuację panującą na ziemiach polskich za „gruntowną banalizację tematu”, stwierdzając, iż nie zauważyłem, że dzięki nim na ziemiach polskich pojawił się „,nowoczesny typ państwa wraz z szeregiem instytucji, do których należała przyszłość i że groteskowy i anachroniczny był nie pruski etatyzm, ale sarmacki liberalizm", zaś wprowadzone w Księstwie Warszawskim rozwiązania były oparte na wzorach pruskich oraz francuskich, „ale i one z sarmatyzmem nic wspólnego nie miały, a z etatyzmem i centralizacją jak najbardziej” (D. Łukasiewicz, Sarmatyzm i Prusy na przełomie XVIII i XIX w., Warszawa 2015, s. 43). Wyjaśniam, że wspomniany fragment mojej pracy, w którym starałem się zresztą podkreślić nie tylko ciemne strony rządów pruskich (pisząc: „Przedstawianie życia «pod pruskim zaborem» wyłącznie w kategoriach narodowej opresji i biurokratycznego koszmaru byłoby jednak znacznym uproszczeniem", s. 37 nn.), nie miał na celu ukazania ewentualnej historycznej doniosłości zmian ustrojowych, które wkroczyły wraz z nimi na ziemie polskie, lecz wyjaśnienie czytelnikowi, dlaczego wielu ówczesnych Polaków wystąpiło przeciw władzy zaborcy, nie bacząc na pewne korzyści, które mogły wynikać z porozbiorowych porządków. W lapidarnym skrócie ujął to Rajmund Rembieliński w liście do Józefa Kalasantego Szaniawskiego: „Rząd jego [króla pruskiego - J.C.] był najznośniejszym spomiędzy trzech i na logicznych pryncypiach wsparty; lecz, że chciał Polaków zupełnie po niemiecku urządzić, zrodził przez to samo w ich sercu wieczną reakcją, która na koniec zguby i ukarania jego dokonała”, zaś nastrojów wrogich pruskiej władzy „nawet powiększenie, polepszenie dostatków każdego prywatnego przezwyciężyć ogólnie nie zdołało" (Korespondencja w materiach obraz kraju i narodu rozjaśniających, wyd. J.K. Szaniawski, Warszawa 1807, List 30, s. 211-212). Istotnie, u schyłku XVIII w. „przyszłość należała” do rozwiązań ustrojowych opartych na „etatyzmie i centralizacji”. Ustrojów odwołujących się do nich w mniejszym stopniu lub wykorzystujących je jedynie w części nie uważam jednak z góry za anachroniczne (przypadki funkcjonowania i ewolucji 
Rozmaite źródła zastosowanych rozwiązań i wyraźny ukłon w stronę rodzimej tradycji decydować miały, zdaniem niektórych, o specyfice Księstwa Warszawskiego na tle innych protektoratów napoleońskich ${ }^{6}$. Sądzę, że kwestia ta nadal wymaga przeprowadzenia dokładnych badań porównawczych. Istnieją przesłanki wskazujące, że mimo podobieństwa w kwestii głównych zasad ustrojowych, w państwach znajdujących się w orbicie wpływów Napoleona lub na terytoriach bezpośrednio włączonych do cesarstwa funkcjonujące w nich lokalne tradycje polityczne, rozwiązania prawno-ustrojowe, wzorce i praktyki administrowania mogły przetrwać w stopniu większym, niż dotąd uważano7.

Niewątpliwie jednak w Księstwie Warszawskim dokonał się wyraźny zwrot w kierunku koncentracji władzy w ręku monarchy, zwiększenia uprawnień władzy wykonawczej, ale także poszerzenia sfer życia społecznego i gospodarczego, których dotyczyć miały jej działania. Wraz z ograniczeniem kompetencji ciał przedstawicielskich i wprowadzeniem nowych zasad określających możliwości partycypacji obywateli w sprawach publicznych tworzyło to system polityczny o cechach nieznanych polskiej tradycji i niezakorzenionych w mentalności politycznej szlachty.

Jak zauważyła Anna Grześkowiak-Krwawicz, w polskim dyskursie politycznym w XVIII w., mimo zmian zachodzących w nim w latach osiemdziesiątych, kluczową rolę odgrywało pełne utożsamienie się obywateli z państwem, oparte na przekonaniu, że każdy z nich ,jest członkiem «krajowej zwierzchności»" i powinien mieć wpływ na proces legislacyjny oraz podejmowanie najważniejszych decyzji w sferze życia politycznego: „Propozycje powierzenia władzy «zwierzchności» niezależnej od woli narodu były w polskiej teorii politycznej niesłychanie rzadkie [--], jeszcze rzadziej uznawano je za niesprzeczne z wolnością obywateli" ". W tym kontekście pobieżny nawet przegląd głównych postanowień nadanej przez Napoleona konstytucji mógł budzić obawy wielu obserwatorów, że w sporze „między majestatem a wolnością”, mającym długą

ustrojów politycznych Wielkiej Brytanii, Stanów Zjednoczonych czy Szwajcarii tworzą $\mathrm{w}$ tej mierze ciekawe pole obserwacji, podobnie w przypadku polskim krótki okres po Konstytucji 3 maja). o „sarmatyzmie” ani „sarmackim liberalizmie” nie wspominałem w swej pracy. Przydatność tych pojęć jako narzędzi do analizy kwestii prawno-ustrojowych wydaje mi się wątpliwa, ale, nie chcąc ryzykować gruntownej banalizacji tematu, nie podejmuję dyskusji w tej mierze.

${ }^{6}$ W. Sobociński, op. cit., s. 126-127; P. Cichoń, op. cit., s. 19.

7 Kwestia ta pojawia się np. w artykułach zawartych w zbiorze Collaboration and Resistance in Napoleonic Europe. State-Formation in an Age of Upheaval, c. 1800-1815, red. M. Rowe, Basingstoke-New York 2003.

${ }^{8}$ A. Grześkowiak-Krwawicz, Regina libertas. Wolność w polskiej myśli politycznej XVIII w., Gdańsk 2006, s. 106-107, 108, 150. 
tradycję w polskiej kulturze politycznej, szala przechyliła się na stronę panującego. Wyrazem poglądów środowisk ,dobrze myślących, starożytnych Polaków", przywiązanych do dawnych tradycji ustrojowych, stała się anonimowa satyra, której rękopiśmienne wersje krążyły po kraju do 1814 r., w ostry sposób krytykująca nowe prawa i instytucje9 ${ }^{9}$. Już w lipcu 1807 r. kryzys nastrojów w kręgach zainteresowanych sprawami publicznymi był zauważalny dla polskich i francuskich obserwatorów. Wydaje się, że spowodowały go przede wszystkim informacje o dalekich od oczekiwań przebiegu granic i nazwie nowego państwa. Zapewne wieści o rozwiązaniach prawno-ustrojowych zawartych w konstytucji również nie wszystkich skłaniały do optymizmu. Na przełomie 1806 i $1807 \mathrm{r}$. jedynie w niezbyt licznym gronie dawnych polskich jakobinów oczekiwano, że w odbudowanej przez Napoleona Polsce wprowadzone zostaną konstytucja wzorowana na francuskiej i Kodeks Cywilny ${ }^{10}$. Środowisko szlachty i arystokracji związanej niegdyś z reformami Sejmu Wielkiego, którego przedstawiciele przeważali w kręgach odbudowanej w ciągu kilku miesięcy polskiej administracji, wyraźnie liczyło na przywrócenie Konstytucji 3 maja, w najlepszym razie nieco zmienionej. Jej egzemplarz zabrała do Drezna Komisja Rządząca w nadziei przekonania Napoleona, iż Ustawa Rządowa zawiera rozwiązania najlepiej dostosowane do polskich realiów ${ }^{11}$.

Z raportów francuskiego rezydenta w Warszawie i korespondencji marszałka Louisa Nicolasa Davouta wynika jednak, że w ciągu kilku tygodni atmosfera w kraju poprawiła się, by sięgnąć niemal entuzjazmu podczas wizyty Fryderyka Augusta w kraju u schyłku 1807 r. ${ }^{12}$ Głosy malkontentów nie zamilkły - jeszcze rok później Hugo Kołłątaj odniósł się do nich w publikacji opatrzonej znamiennym motto: nil desperandum ${ }^{13}$, można jednak przypuszczać, że znacząca część opinii publicznej jeśli nie w pełni zaakceptowała nowy system polityczny, to przynajmniej pogodziła się z myślą, że chwilowo nie ma dla niego alternatywy.

${ }^{9}$ Książka katechizmu przez Twórcę dla ministrów i wszelkich stanów sporządzona, z której można się wiele zbudować poczciwym, dobrze myślacym, starożytnym Polakom roku 1814 wydana albo opis katechizmowy uszczęśliwienia Księstwa Warszawskiego od jego narodzenia, czyli od roku 1807, „Regiony” 1998, 1-3, s. 212.

10 Por. J. Zajączek do Napoleona, przed 25 XII 1806, Z korespondencyi gen. Zajączka 1806, 1807, 1811 i 1812, w: A.M. Skałkowski, O cześć imienia polskiego, Oświęcim 2015, s. 220.

${ }^{11} \mathrm{~J}$. Wybicki, Życie moje oraz wspomnienie o Andrzeju i Konstancji Zamoyskich, wyd. A.M. Skałkowski, Wrocław 2005, s. 350-352; W. Zajewski, Józef Wybicki, Warszawa 1983, s. 204-205.

12 J. Czubaty, Księstwo Warszawskie, s. 152, 154, 159.

${ }^{13}$ H. Kołłątaj, Uwagi nad położeniem tej części ziemi polskiej, którą od pokoju tylżyckiego zaczęto zwać Księstwem Warszawskim, Lipsk [właśc. Warszawa] 1808, s. 72-73. 
Nie wszystkim przyszło to łatwo, istniało jednak kilka argumentów skłaniających do pogodzenia się z nową rzeczywistością polityczną. Do najsilniej przemawiających należały zapewne wnioski płynące $z$ doświadczenia braku własnego państwa i pamięć o niedawnych obawach o przyszłość narodu „w obcych narodów bryłę przelanego"14. Wobec braku konkretnych propozycji ze strony władców mocarstw zaborczych, „wskrzeszenie” Królestwa Polskiego wydawało się możliwe jedynie dzięki protekcji Napoleona, co oznaczało konieczność przyjęcia narzuconych przez niego wzorców prawno-ustrojowych. W tej mierze prawie nie było miejsca na negocjacje. Ludwik Gutakowski, relacjonując spotkanie z ministrem sekretarzem stanu Hugues'em Maretem, podczas którego Komisja Rządząca zapoznała się z ostateczną wersją konstytucji, wspominał: „Uważaliśmy wiele odmian dla nas nie bardzo przyzwoitych, z popraw zaś w czasie pierwszego czytania czynionych żadnej umieszczonej nie znaleźliśmy [--]. Na koniec trzeba było podpisać"15.

Akceptacji zmian sprzyjać mogło także kilkunastoletnie obcowanie ze zbiurokratyzowanym aparatem władzy państwa pruskiego - obcego, ale w porównaniu z Austrią i Rosją uznawanego przez wielu za najmniej opresyjne dla Polaków, sprawne i - jak zauważał Rajmund Rembieliński - „na logicznych pryncypiach wsparte”. W podobny sposób oddziaływać mogły również wnioski z obserwacji rządów Napoleona we Francji. Dość typowy ich przykład stanowią zapiski w dzienniku z podróży Juliana Ursyna Niemcewicza w 1804 r. Pisarz, daleki od entuzjazmu dla pierwszego konsula, odnotowywał liczne osiągnięcia jego rządów, konkludując: „Moralność jest u niego głupstwem; co tylko jest pożytecznego, potrzebnego, uzna, czy własnej ambicji, czy wielkości narodu, nad którym dziś panuje, i mniejsza, czy trucizną, mieczem, zdradą dopiąć musi - dopnie. Jest to Tamerlan, Czyngiz-chan, z światłem, polorem i nauką XIX wieku. [--] Czemuż zamiast Stanisława Augusta w trudnych zapasach naszych on berłem naszym nie władał?"16. Z napoleońskimi wzorcami ustrojowymi i praktyką sprawowania władzy oswajały częste u progu XIX w. wojaże przedstawicieli polskiej arystokracji do Paryża. W kręgu polskiej kolonii w stolicy cesarstwa zwracano uwagę nie tylko na uroki życia towarzyskiego i przepych cesarskiego dworu. Oto Stanisław Zamoyski

14 T. Kizwalter, O nowoczesności narodu. Przypadek polski, Warszawa 1999, s. 106-107, 131-133; J. Czubaty, Zasada „dwóch sumień”. Normy postępowania i granice kompromisu politycznego Polaków w sytuacjach wyboru (1795-1815), Warszawa 2005, s. 105-113.

${ }^{15}$ Cyt. za: E. Machalski, Ludwik Gutakowski. Prezes Rady Stanu i Ministrów, Dubno 1938, s. 38.

${ }^{16}$ J.U. Niemcewicz, Podróże po Ameryce 1797-1807, z rkp. wyd., wstęp i objaśn. A. Wellman-Zalewska, red. E. Kipa, Wrocław-Warszawa 1959, s. 346. 
w jednym ze swych listów podkreślał zasługi Napoleona dla odbudowy zachwianej przez rewolucję moralności Francuzów oraz rozwoju szkolnictwa i gospodarki kraju. Atanazy Raczyński, komentując po latach wpis w swym dzienniku z 1813 r., pisał: „Ależ byłem wówczas napoleonistą... [--] Marzyłem o Polsce pod silnymi rządami, takimi, jakich można było się spodziewać po żelaznej ręce Bonapartego"17.

Elita polityczna Księstwa Warszawskiego na poziomie centralnym i lokalnym wywodziła się w przeważającej mierze z kręgów szlachty i arystokracji bezpośrednio lub pośrednio zaangażowanych $\mathrm{w}$ działalność obozu reformatorskiego na Sejmie Wielkim. Wydaje się, że większemu otwarciu tych środowisk na rozwiązania ustrojowe odbiegające od rodzimych wzorców sprzyjać mogły również doświadczenia wyniesione z dyskusji toczonych w latach 1788-1792, choćby sporu o sukcesję tronu. Uczestniczące w nim strony chętnie odwoływały się do przykładów systemów politycznych w innych państwach europejskich, samą debatę zaś Grześkowiak-Krwawicz określiła jako starcie „dwóch sposobów myślenia o państwie. Dawnego - nastawionego na obronę sytuacji istniejącej, niechętnego wszelkim zmianom [--] i nowego, który nie tylko dopuszczał możliwość zmian, ale wręcz uznawał ich niezbędność, który chciał nie tylko bronić wolności pozostawionej przez przodków, ale tworzyć nowoczesne państwo"18.

Do akceptacji nowego porządku skłaniać mogła także - obecna już w publicystyce przedrozbiorowej - krytyczna ocena funkcjonowania systemu politycznego Rzeczypospolitej stwarzającego warunki sprzyjające dominacji wielkich rodów. Kwestia ta wraz z upadkiem rządów pruskich powróciła do dyskursu publicznego, wzmocniona przez przekonanie, że to destabilizujące państwo spory magnackich fakcji były jedną z głównych przyczyn upadku Polski. Zarzut ów, obecny w publicystyce i korespondencji polskich emigrantów po drugim i trzecim rozbiorze, dobitnie powtórzył Stanisław Staszic w głośnej rozprawie opublikowanej w początkach 1807 r., przestrzegając przed skutkami powrotu do władzy tych, którzy naród ,jedni przez dumę i złość, drudzy przez nieumiejętność i głupstwo, przyprowadzili do zguby; aby się przez takich odradzał, przez jakich był zgubiony, zachowaj go Boże od magnatów!"19.

17 J. Skowronek, Aleksander Sapieha. Z magnackiego gniazda do napoleońskiego wywiadu, Warszawa 1992, s. 66; A. Raczyński, Dziennik, t. 1, wpis z 30 V 1813. Za udostępnienie tekstu przygotowywanego do druku dziękuję Michałowi Mencfelowi.

18 A. Grześkowiak-Krwawicz, o formę rządu, czy o rząd dusz? Publicystyka polityczna Sejmu Czteroletniego, Warszawa 2000, s. 87, 257, 261.

19 S. Staszic, O statystyce Polski: krótki rzut wiadomości potrzebnych tym, którzy ten kraj chca oswobodzić i tym, którzy w nim chca rządzić, Warszawa 1807, s. 17-18. 
Eksklamacja wyrażała nie tylko osobiste poglądy publicysty od lat znanego jako przeciwnik ustroju stanowego. Wielu obserwatorów życia politycznego i jego uczestników obawiało się powrotu wpływów potężnych rodów, grożącego odrodzeniem się „ducha fakcji”. Pojęcie to opisywało pewną cechę mentalności politycznej, zarazem sprzyjającej osłabiającym niegdyś państwo sporom magnackich koterii i wzmacnianej przez nie. U progu Księstwa Warszawskiego i w późniejszych latach jego istnienia „duch fakcji”, zwykle łączony z „nierządem” lub „anarchią”, występował w dyskursie publicznym jako jedno z największych zagrożeń dla bytu państwa i przyszłej odbudowy Królestwa Polskiego ${ }^{20}$.

Zdaniem Staszica, odsunąć je mogła zasadnicza zmiana ustroju: „Jemu [narodowi - J.C.] trzeba czym prędzej króla; a króla z mocą jedynowładztwa, z duchem wielkim stałości i męstwa - króla bohatera" ${ }^{21}$. Przekonanie o konieczności wzmocnienia władzy wykonawczej skupionej w ręku monarchy żywili także dawni republikanie. U progu Księstwa Warszawskiego środowisko insurekcyjnych jakobinów, z których wielu przewinęło się później przez szeregi Towarzystwa Republikanów Polskich, zrezygnowało już z części radykalnych haseł i form działania, jednak konsekwentnie opowiadało się za wcieleniem w życie najważniejszych postulatów rewolucji francuskiej, przede wszystkim zasady równości wobec prawa. Napoleona postrzegano jako potężnego protektora, który odbuduje Polskę i narzuci jej ustrój przyspieszający transformację społeczną. Dzięki temu, jak zauważyła Barbara Grochulska, w przekonaniu republikanów Polacy mieli odnieść korzyści płynące z rewolucyjnych przemian bez „krwawej roboty, rewolucji, która była ceną uzyskanego postępu”22.

Przekonanie to wyraźnie przebijało w zainicjowanej przez republikanów, zainspirowanej publikacją Staszica debacie prasowej na temat potrzeb kraju. Jeden z jej uczestników, podsumowując zyski, jakie przyniesie Polakom nadana przez Napoleona konstytucja, podkreślał szczególnie wpływ jej zapisów na położenie chłopów oraz zalety Kodeksu Napoleona - „cywilnego prawodawstwa, które sprawiedliwie uważać można jako dokładny wyraz dzisiejszej cywilizacji i uprawy społecznej". Moment dziejowy, w którym znaleźli się Polacy, określał jako „chwilę przechodu ku nowemu porządkowi rzeczy”. Jego sprawny przebieg zapewnić powinno - to przekonanie, według mnie, wyraźnie

${ }^{20}$ J. Czubaty, Zasada „dwóch sumień”, s. 298, 315, 390-392.

${ }^{21}$ S. Staszic, op. cit., s. 18.

22 B. Grochulska, Lewica wobec Napoleona w świetle „Korespondencji w materiach obraz kraju i narodu rozjaśniających", w: Francja-Polska. XVIII-XIX w. Studia z dziejów kultury i polityki poświęcone prof. Andrzejowi Zahorskiemu w sześćdziesiąta rocznicę urodzin, red. A. Mączak, Warszawa 1983, s. 68. 
przebija z opublikowanej korespondencji „krajowców” - państwo silniejsze i lepiej zorganizowane niż dawniej. Józef Lipiński, w przyszłości sekretarz Izby Edukacyjnej Księstwa, kreśląc obraz nieszczęść wywołanych przez „niesforność” w czasach przedrozbiorowych, zauważał: „Nie masz już nikogo, który by nie żądał porządku dzielnej i jednej władzy narodowej"23.

Historia pojęć w Polsce nadal czeka na opracowanie. Badania nad zmianami zachodzącymi $\mathrm{w}$ aparacie pojęciowym byłyby szczególnie interesujące $\mathrm{w}$ przypadku pokolenia aktywnego w życiu politycznym i intelektualnym u schyłku XVIII i w początkach XIX w. W przywołanych opiniach Staszica i Lipińskiego zwraca uwagę to, że postulaty władzy „dzielnej i jednej władzy narodowej”, a zwłaszcza „króla z mocą jedynowładztwa”, zdecydowanie różniły się od haseł „rządności” i ,systematycznego rządu" ${ }^{24}$ głoszonych niegdyś przez zwolenników Konstytucji 3 maja.

Znacznie silniejszą niż dawniej władzę monarchy gotowi byli zaakceptować nie tylko dawni insurekcyjni radykałowie i ich sympatycy. 20 czerwca 1810 r., pod wrażeniem krytycznych opinii na temat stanu państwa, ujawniających się podczas toczonych w poprzednim roku obrad sejmu, podobnych uwag saskich ministrów, ale także części kręgów rządzących Księstwem, Fryderyk August powołał deputację, która miała przygotować raport przedstawiający możliwości usprawnienia działań administracji, zmniejszenia kosztów jej funkcjonowania oraz zwiększenia dochodów państwa. Składała się ona z przedstawicieli Rady Stanu - siedmiu radców i referendarza ${ }^{25}$. Choć dwu z nich - Staszica i Aleksandra Linowskiego - można uznać za sympatyzujących z kręgiem dawnych jakobinów lub znajdujących się wówczas pod jego wpływem ${ }^{26}$, większość stanowili reprezentanci środowiska, dla którego naturalny punkt odniesienia w kwestiach ustrojowych stanowiły wzorce Ustawy Rządowej. W raporcie podsumowującym działalność deputacji z 19 stycznia 1811 r. znalazły się jednak sformułowania wskazujące na akceptację modelu ustrojowego w znacznym stopniu różniącego się od niej. Oceniając system polityczny Księstwa Warszawskiego, autorzy raportu stwierdzali: „najpiękniejszym w teorii dzisiejszych rządów i konstytucji wynalazkiem jest to, czego nasz

${ }^{23}$ J. Lipiński do ks. K. Szaniawskiego, Korespondencja w materiach, List 19, s. 128; J.K. Szaniawski do A. Horodyskiego, ibidem, List 26, s. 172-173, 176.

${ }^{24}$ A. Grześkowiak-Krwawicz, o formę rządu, s. 329.

25 J. Willaume, Fryderyk August jako książę warszawski (1807-1815), Oświęcim 2013, s. 177-179; dekret z 20 VI 1810 r., w: Ustawodawstwo Księstwa Warszawskiego. Akty normatywne władzy najwyższej, t. 2: 1809-1810, oprac. W. Bartel, J. Kosim, W. Rostocki, Warszawa 1964 , s. $164-165$.

${ }^{26}$ B. Grochulska, Księstwo Warszawskie, Warszawa 1966, s. 181. 
naród najwięcej potrzebował, a od czego nas nieszczęśliwe długo oddalały okoliczności, to jest aby była moc skoncentrowana, tłumiąca swą wyższością i przewagą wszystkie szczególne namiętności [--]. Moc ta znajduje się w koncentracji woli rządzącej, woli jednej i równej samemu prawu położona w osobie na najwyższym szczeblu dziedzicznie postawionej"27.

Podobne przekonanie o pozytywnych dla kraju i narodu skutkach silnej władzy monarszej żywiła także przynajmniej część przedstawicieli elity lokalnej. 14 grudnia 1811 r. posłowie i deputowani zgromadzeni na nieformalnej sesji sejmowej, przekraczając konstytucyjne kompetencje Izby Poselskiej, przyjęli adres do Fryderyka Augusta. Apelowali w nim o natychmiastowe reformy, mające na celu zażegnanie kryzysu, w jakim znalazło się państwo na skutek pospiesznego wprowadzania nowych praw, błędów popełnionych podczas organizacji administracji, nadużyć z jej strony oraz źle skonstruowanego systemu podatkowego. Księstwo Warszawskie, stwierdzali, nadal „nie wyszło jeszcze z początkowego zamieszania”. Sytuacja w nim panująca to „bezrząd” i wynikający z niego powszechny ucisk mieszkańców ${ }^{28}$. Starając się złagodzić wrażenie, jakie niezgodna z konstytucją inicjatywa Izby Poselskiej mogła wywrzeć na królu, autorzy adresu podkreślali, że nie jest on aktem nieposłuszeństwa, lecz wyrazem ufności w jego ojcowski stosunek do poddanych. Wyraźnie też starali się odsunąć zarzut przywiązania do tradycji demokracji szlacheckiej, której wady, w ich ujęciu, stały się jedną z przyczyn rozbiorów: „Naród nasz tylu nieszczęściami znękany nie jest to więcej ów naród zbytnią wolnością i powodzeniami zepsuty. Zna on całą okropność anarchii, zna oraz twarde obcej niewoli jarzmo. [--] Najjaśniejszy Panie! Chcemy abyś jeden nami rządził - uznajemy rząd w osobie W.K. Mci, przestaliśmy już od dawna smakować we władzy arystokratów, bo doświadczenie nauczyło nas, że oni byli sprawcami anarchii w kraju naszym, że oni nad życie polityczne narodu i jego imię swe możnowładztwo i trwanie swych nazwisk przenoszą"29.

Tak demonstracyjne podkreślenie w raporcie deputacji i adresie Izby Poselskiej uznania dla zasady skoncentrowania władzy „w osobie króla" zasługuje na szczególną uwagę jako sygnał dokonujących się przemian mentalności politycznej. Najwyraźniej obejmowały one nie tylko kręgi rządzące Księstwem Warszawskim, ale też środowiska, które część

27 BPAU-PANKr, rkp. 139, Raport deputacji, 19 I 1811, k. 45v-46 (dalej: Raport deputacji; rękopis niepaginowany, paginacja moja - J.C.).

28 [J. Godlewski], Głosy posła mariampolskiego na sejmie roku $1811 \mathrm{w}$ Warszawie miane $z$ dołączeniem uwag i krótkiego nadmienienia niektórych w czasie sejmu czynności, Warszawa 1814 , s. $6,13$.

${ }^{29}$ Ibidem, s. 4. 
historyków określała mianem „opozycji staroszlacheckiej”30. Sądzę, że jest ono mylące. To jednak kwestia godna odrębnej dyskusji. Nie ulega natomiast wątpliwości, że choć pewne aspekty nowego porządku rzeczy mogły budzić niezadowolenie, do jego akceptacji (przynajmniej czasowej) skłaniały krytyczna ocena funkcjonowania przedrozbiorowego modelu państwa i doświadczenie pozostawania pod obcą władzą. Księstwo Warszawskie traktowano jako rozwiązanie tymczasowe, ośrodek przyszłych działań na rzecz obudowy Królestwa Polskiego. Konieczność jego sprawnej organizacji, zapewniającej wykorzystanie dziejowej szansy, z pewnością również stanowiły argument na rzecz pogodzenia się z nowymi rozwiązaniami ustrojowymi. W najwyższym kręgu elity rządzącej Księstwem skłaniała ku temu także narastająca już w czasach przedrozbiorowych wśród młodych, uznających konieczność reform arystokratów „tęsknota za prawdziwym państwem i prawdziwą władzą"31. Napoleońska konstytucja składała ją w ręce króla - ten jednak na co dzień przebywał w Saksonii, co znacznie poszerzało zakres rzeczywistej władzy ministrów.

Księstwo Warszawskie istniało niespełna osiem lat. Jego względna samodzielność polityczna trwała mniej niż sześć lat - wiosną $1813 \mathrm{r}$. całe jego terytorium, $\mathrm{z}$ wyjątkiem broniących się nadal twierdz, znalazło się pod okupacją rosyjską. To krótko, zwłaszcza jeśli wziąć pod uwagę skalę oczekiwań wobec tworu państwowego, który Grochulska trafnie nazwała „małym państwem wielkich nadziei” ${ }^{2}$. W przypadku większości zainteresowanych sprawami publicznymi sprowadzały się one do możliwości przekształcenia go we „wskrzeszone” dzięki protekcji Napoleona Królestwo Polskie. Istniały jednak liczące się środowiska, które dostrzegały także inne możliwości, jakie otwierało przed Polakami. Jeszcze przed utworzeniem Księstwa Warszawskiego swe oczekiwania na doprowadzenie kraju do „kwitnącego stanu” dzięki zaprowadzeniu w nim silnego rządu wyraźnie formułował Staszic, pisząc o konieczności uspławniania rzek, budowy kanałów i bitych dróg, intensyfikacji produkcji rolnej czy rozwoju rzemiosła i handlu ${ }^{33}$. Wątek ten wyraźnie zaznaczał się w korespondencyjnej dyskusji zainicjowanej przez dawnych republikanów. Mądry rząd miał zatem „okolice Polski, raczej do dzikich stepów podobne, przeistoczyć w kraj [--] obfity, rządny, ozdobny miastami,

${ }^{30}$ Por. np. A. Rosner, Sędziowie i urzędnicy sądów pokoju w Księstwie Warszawskim, PH 79, 1988,4 , s. 682.

31 B. Grochulska, Kraków w systemie warszawsko-francuskim, w: Kraków w czasach Księstwa Warszawskiego. Materiały sesji naukowej z okazji Dni Krakowa w roku 1988, Kraków 1989, s. 12-13.

32 B. Grochulska, Małe państwo wielkich nadziei, Warszawa 1987.

33 S. Staszic, op. cit., s. 10-11, 16. 
wsiami porządnemi; będziemy mieli murowane drogi, mosty bezpieczne, fortece, wojsko bitne, skarb bogaty, kanały, rzeki spławne, handel i więcej podobnych a nieodbicie potrzebnych rzeczy" ${ }^{\prime 34}$.

W tym samym liście zaznaczono także inne oczekiwania związane z dobroczynnym działaniem zasady równości wobec prawa, która sprawi, że „nie będzie innej różnicy między nami, tylko ta jedynie, którą zasługa i cnota oznaczy"35. Nadzieje związane z mającą nastąpić przebudową starych struktur i zdynamizowaniem procesów społecznych formułowali także inni korespondenci, szkicując perspektywę otwarcia karier nauczycielskich, urzędniczych i oficerskich dla chłopów, „skruszenia do reszty przesądów, jeżeli jeszcze jakie szlachcica od osiadania w miastach i zajęcia się przemysłem miejskim odwodzą" czy reformy duchowieństwa, które „pod okiem rządu” zacznie „pracować dla dobra kraju” ${ }^{36}$. Postulatem często przewijającym się w listach była także rozbudowa edukacji elementarnej. Ów „przechód do nowego” miał się dokonać dzięki energicznym działaniom rządu - jak ujął to profesor gimnazjum poznańskiego Jan Samuel Kaulfus: „Rząd dzielną ręką czynności ludu swego dążące do szczęścia kierować musi”37.

Przekonanie o dominującym wpływie, jaki władza wykonawcza powinna wywierać za pośrednictwem urzędników na proces przemian w kraju, ujawniało się również w późniejszych latach, przede wszystkim w kręgach elit mieszczańskich oraz rodzącej się inteligencji, której przedstawiciele często znajdowali zatrudnienie w rozlicznych urzędach i szkolnictwie. Za typową dla nastrojów przedstawicieli owych środowisk można uznać mowę wygłoszoną w 1809 r. w Towarzystwie Przyjaciół Nauk przez adwokata Ignacego Stawiarskiego, w której roztaczał on przed słuchaczami „przyjemny widok kraju, który ojcowska administracja użyźnia, zbogaca i kwitnącym czyni!"38. Najbardziej może dobitny głos w tej kwestii zabrał Wawrzyniec Surowiecki w wygłaszanych w latach 1812-1813 wykładach w Szkole Prawa i Administracji. W jego ujęciu, istnienie licznej klasy urzędników to nieunikniona konieczność związana z rozwojem, bowiem „z każdym stopniem oświecenia i ludności drobią się

${ }^{34}$ J. Neyman do J.N. Małachowskiego, Korespondencja w materiach, List 33, s. 225.

35 Ibidem, s. 227.

${ }^{36}$ A. Gliszczyński do J.K Szaniawskiego, ibidem, List 3, s. 16, 18; tenże do A. Horodyskiego, ibidem, List 21, s. 134; List 34, o potrzebie rządowego nad duchowieństwem dozoru, przez X. W.P.G., ibidem, s. 238.

37 Por. A. Ziemięcki do J. Neymana, ibidem, List 35, s. 245-248; J. Kaulfus do J.K. Szaniawskiego, ibidem, List 36, s. 248.

38 Cyt. za: M. Mycielski, „Miasto ma mieszkańców, wieś obywateli”. Kajetana Koźmiana koncepcje wspólnoty politycznej (do 1830 roku), Wrocław 2004, s. 38. 
sprawy, za tym obowiązki, a następnie osobni urzędnicy". Tendencję tę Surowiecki postrzegał jako korzystną dla kraju. W jego wizji, urzędnik to nie przedstawiciel bezdusznej machiny administracyjnej, lecz filantrop w służbie państwa i jego obywateli: „Co za rozkosz dla niego, gdy sam swoją ręką otrze ostatnią łzę nieszczęśliwemu, gdy strapiony w progach jego znajdzie prawdziwą pociechę dla siebie, słaby - pomoc, ciemny oświecenie, obłąkany - radę, ułomny - ludzkość; gdy wszyscy uciekają się do niego w szczęściu i nieszczęściu jak do przyjaciela i ojca"39. W środowisku elity intelektualnej, ale także wśród części przedstawicieli kręgów rządzących, by wspomnieć ministra sprawiedliwości Feliksa Łubieńskiego, za jedno z głównych zadań stojących przed rządzącymi uznawano stworzenie w państwie warunków, które pozwolą nadrobić zapóźnienie cywilizacyjne kraju i otworzą drogę do nowoczesności. W jakim stopniu oczekiwania te udało się zrealizować? Czy Księstwo Warszawskie było pierwszym nowoczesnym polskim państwem?

Niniejszy tekst nie stanowi głosu w dyskusji na temat istoty nowoczesnego państwa. Na użytek niniejszych rozważań przyjmuję kilka założeń Anthony'ego Giddensa, które mogą okazać się przydatne. Za najważniejszą cechę nowoczesnego państwa uznał on jego zdolność do „skoordynowanej kontroli nad obszarami, które obejmuje”. Umożliwia ją koncentracja władzy administracyjnej oraz pojawienie się aparatu nadzoru pozwalającego na kontrolę nad działaniami ludności w sferze politycznej. Może ona mieć charakter bezpośredni (realizowana choćby za pośrednictwem systemu penitencjarnego lub szkolnictwa) lub pośredni (np. sprawowana poprzez kontrolę przepływu informacji). Istotną cechą państwa nowoczesnego jest również utrzymywanie przez nie monopolu w zakresie środków przemocy, opartego na świeckim autorytecie nowych kodeksów prawa karnego ${ }^{40}$. Powyższą definicję można uzupełnić o uwagę Jürgena Habermasa, który nowoczesność państwa dostrzegał w jego zdolności do stymulowania lub wspierania nowej integracji kulturowej związanej z rodzącą się świadomością narodową zamieszkującej je zbiorowości. Tego typu organizm państwowy tworzy ponadto warunki, w których możliwe jest działanie „kumulatywnych i wzajemnie wspierających się procesów, takich jak: powstawanie kapitału i gromadzenie zasobów; rozwój sił wytwórczych i wzrost wydajności pracy; centralizacja władzy politycznej i kształtowanie się narodowych tożsamości; upowszechnienie praw politycznego uczestnictwa, [--] formalnej edukacji szkolnej"

${ }^{39}$ W. Surowiecki, O statystyce Księstwa Warszawskiego, w: idem, Wybór pism, oprac. J. Grzywicka, A. Łukaszewicz, Warszawa 1957, s. 275, 279, 352.

40 A. Giddens, Konsekwencje nowoczesności, Kraków 2008 (oryg. ang. 1990), s. 42-44. 
itp. Nie wszystkie ze wspomnianych procesów muszą działać w równym tempie i z podobną intensywnością we wszystkich regionach ${ }^{41}$.

Księstwo Warszawskie spełniało część tak określonych kryteriów państwa nowoczesnego. Dokonała się w nim, jak wspomniano, znacząca centralizacja władzy. Jednym z jej skutków w praktyce rządzenia była ogromna liczba zarządzeń transmitowanych od władz centralnych do lokalnych, dotyczących także spraw drobnych, rozstrzyganych dawniej na poziomie lokalnym - praktyka znana z czasów pruskich, w przypadku polskiego rządu nowa. Centralizacja pozwalała kręgom rządzącym przynajmniej aspirować do sprawowania szerszej kontroli w sferze postaw politycznych. Do jej instrumentów należały rozbudowana cenzura prasy i publikacji oraz intensywne działania propagandowe - zjawiska typowe dla systemu napoleońskiego. Służyły one nie tylko blokowaniu informacji z różnych względów uznanych za niekorzystne dla władz Księstwa czy jego protektora, ale także umacnianiu „ducha narodowego”, propagowaniu oczekiwanych postaw czy krzewieniu moralności ${ }^{42}$. Obszarem działań o charakterze wychowawczo-kontrolnym było również szkolnictwo, którego rozwój zwłaszcza na poziomie elementarnym i średnim budzi uznanie badaczy ${ }^{43}$. Warto zwrócić uwagę na - również wzorowaną na Francji - praktykę ogłaszania aktów prawnych w urzędowym „Dzienniku Praw” oraz „Dziennikach Departamentowych”. W tych ostatnich publikowano także liczne rozporządzenia oraz porady i pouczenia dotyczące zasad gospodarowania, higieny i zdrowia ${ }^{44}$. Wydaje się, że inicjatywy te należy uznać za istotne novum w zakresie kontaktowania się władz z obywatelami.

Do nowoczesności zbliżały również Księstwo Warszawskie zmiany w zakresie obowiązującego prawa, związane nie tylko z przyjęciem Kodeksu Napoleona, ale także wprowadzonym w 1809 r. francuskim kodeksem handlowym, którego zapisy z jednej strony poprawiały sytuację prawną mieszczańskich kupców, z drugiej - stwarzały warunki umożliwiające aktywizację szlachty na polu handlu ${ }^{45}$. Choć podczas

${ }^{41}$ J. Habermas, Obywatelstwo a tożsamość narodowa. Rozważania nad przyszłościa Europy, Warszawa 1993 (oryg. niem. 1992), s. 8; idem, Filozoficzny dyskurs nowoczesności, Kraków 2005 (oryg. niem. 1985), s. 10.

${ }^{42}$ K. Ossowski, Prasa Księstwa Warszawskiego, Warszawa 2004, s. 39-47.

43 A. Winiarz, Szkolnictwo Księstwa Warszawskiego i Królestwa Polskiego (1807-1831), Lublin 2002, s. 521-522; B. Grochulska, Księstwo Warszawskie, s. 121-123.

${ }^{44}$ M. Kallas, Dzienniki departamentowe $w$ czasach Księstwa Warszawskiego (1808-1815), „Rocznik Historii Czasopiśmiennictwa Polskiego” 10, 1971, 1, s. 26-28; K. Ossowski, op. cit., s. 175-176, 184-188.

${ }^{45}$ B. Grochulska, Księstwo Warszawskie, s. 113. 
sejmu 1811 r. z obawy przed reakcją opozycji w Izbie Poselskiej wycofano spod obrad projekt kodeksu karnego wzorowanego na francuskim, warto zauważyć, że to właśnie w ostatnich latach Księstwa Warszawskiego rozpoczęto dyskusje i prace nad nową kodyfikacją w tej dziedzinie. Ich efektem był Kodeks Karzący przyjęty przez sejm Królestwa Polskiego w 1818 r. ${ }^{46} \mathrm{~W}$ trakcie jego obrad przyjęto także poprawki w zakresie kilku kwestii regulowanych przez Kodeks Napoleona. Sądzę, że dowodzi to nie tylko silnego przekonania elity politycznej o konieczności przygotowania dostosowanych do specyfiki kraju kodeksów narodowych, ale również zrozumienia przez nią korzyści płynących z przyjęcia nowoczesnych, spójnych kodyfikacji. To również skutek kroku w nowoczesność, który dokonano w czasach Księstwa Warszawskiego ${ }^{47}$.

Napoleoński protektorat na ziemiach polskich trudno uznać za przykład państwa efektywnie stymulującego modernizację gospodarki. Warto jednak zwrócić uwagę, że w jego ramach dokonywały się istotne w dłuższej perspektywie przemiany w sferze rolnictwa czy zmiany kierunków handlu zagranicznego. Narzuconej Księstwu blokady kontynentalnej nie należy traktować wyłącznie jako przeszkody w jego rozwoju gospodarczym. Stała się ona także czynnikiem wymuszającym przetasowania w sferze własności ziemskiej oraz dostosowanie produkcji rolnej i handlu zagranicznego do nowej sytuacji, m.in. poprzez rozwój przetwórstwa i mocniejsze związki z rynkami Europy Środkowej. Pewne znaczenie dla rozwoju gospodarczego owych ziem w późniejszych dziesięcioleciach miała także kumulacja kapitału w kręgu bogacących się na zamówieniach państwowych wielkich liwerantów. Niektóre z owych karier położyły podwaliny pod znaczącą pozycję kilku rodów przemysłowców i finansistów ${ }^{48}$.

W znacznie większym stopniu do wzorca nowoczesnego państwa zbliżało się natomiast Księstwo Warszawskie pod względem upowszechnienia praw politycznej partycypacji i wpływu na kształtowanie się narodowej tożsamości. W tym kierunku niewątpliwie działały zniesienie poddaństwa chłopów, zasada równości wobec prawa i formalne zniesienie stanó $\mathrm{w}^{49}$, wreszcie przyznanie praw do udziału w wyborach posłów i depu-

${ }^{46}$ A. Rembowski, Z życia konstytucyjnego Księstwa Warszawskiego, Kraków 1900, s. 67-70; Z. Stankiewicz, Królestwo Polskie 1815-1863, w: Historia państwa i prawa Polski, t. 3, s. 523-524.

47 Za inspirujące uwagi w tym względzie dziękuję Annie Rosner.

${ }^{48}$ B. Grochulska, Handel zagraniczny Księstwa Warszawskiego. Z badań nad struktura gospodarcza, Warszawa 1967, s. 273-275; J. Kosim, Losy pewnej fortuny. Z dziejów burżuazji warszawskiej w latach 1807-1830, Wrocław 1972, s. 54.

49 O dyskusjach historyków w tej kwestii wspominam w: Księstwo Warszawskie, s. 321-323. 
towanych także osobom spełniającym wymogi cenzusu majątkowego lub zasłużonym dla państwa. Warto również zwrócić uwagę na królewski dekret z 19 grudnia 1807 r., wprowadzający po raz pierwszy na ziemiach polskich jednolite pojęcie obywatelstwa oderwanego od wcześniejszych konotacji stanowych ${ }^{50}$. Zmiany te poszerzały zbiorowość mogącą, mniej lub bardziej zasadnie, uznawać się za wspólnotę pełnoprawnych uczestników życia publicznego i identyfikującą się z państwem, a w szerszym wymiarze - także z ideą odbudowy Królestwa Polskiego jako głównym celem narodowych dążeń. Ich znaczenie z emfazą podkreślał Surowiecki: „Konstytucja w jednym słowie: znosi się niewola, potargała wszystkie te więzy hańbiące człowieka”, konkludując: „włościanin już u nas jest człowiekiem, już teraz ma ojczyznę, którą może kochać, wspierać i bronić"51.

Podobny skutek miały w dłuższej perspektywie - o rzeczywistym zasięgu zmian i ich tempie można dyskutować - działania zmierzające do modernizacji administracji i wojska. Tworzeniu zawodowej, kompetentnej kadry urzędniczej towarzyszyło wprowadzenie zasady obowiązkowych egzaminów kandydatów na stanowiska administracyjne przed państwowymi komisjami. Mimo trudnej do zniwelowania przewagi ze strony lepiej wykształconych lub bardziej ustosunkowanych kandydatów pochodzenia szlacheckiego, praktyka ta niewątpliwie zwiększała szanse zatrudnienia wykształconych mieszczan w administracji państwowej. W ciągu kilku lat udało się również przygotować szereg norm prawnych i regulacji określających status urzędników ${ }^{52}$. Wiele z nich funkcjonowało także po 1815 r. To w czasach Księstwa Warszawskiego pojawiła się liczna, przynajmniej z punktu widzenia polskiej tradycji, warstwa pracowników administracji. Niektórych wiązało z państwem poczucie misji, o której pisał Surowiecki; wszystkich - pensje pobierane od niego jako pracodawcy. Grupa ta miała, jak się wydaje, świadomość własnej odrębności i znaczenia, o czym świadczą skuteczne naciski wywierane przez Radę Stanu na króla w sprawie przyznania urzędnikom, także nieszlacheckiego pochodzenia, prawa do noszenia mundurów lub specjalnych znaków ${ }^{53}$. To wyraźny sygnał wkraczania nowoczesności także do sfery symbolicznej.

Zmiany stymulujące społeczny awans i przemiany świadomości dokonywały się także za pośrednictwem armii. Dekret z 9 maja $1808 \mathrm{r}$.

50 „Dziennik Praw Księstwa Warszawskiego”, nr 1, Warszawa 1810, s. 4-6; W. Sobociński, M. Senkowska-Gluck, op. cit., s. 79.

${ }^{51}$ W. Surowiecki, op. cit., s. 447-448.

${ }^{52}$ M. Krzymkowski, Status prawny urzędników Księstwa Warszawskiego, Poznań 2004, s. $154-157$.

${ }^{53}$ Ibidem, s. 107-109; B. Leśnodorski, Elementy feudalne i burżuazyjne w ustroju i prawie Księstwa Warszawskiego, CPH 3, 1951, s. 327. 
wprowadzał wzorowany na Francji, zgodny z zasadą równości, powszechny obowiązek służby wojskowej. Jego rygory łagodziły wprawdzie liczne możliwości uzyskania zwolnienia, przysługujące rozmaitym kategoriom popisowych, zaś potrzeby wojenne sprawiły, że pobór według nowych zasad uzupełniano, stosując sprawdzoną wcześniej praktykę wybierania rekrutów z określonej liczby dymów - nowy kierunek w praktyce uzupełniania sił zbrojnych został jednak wyznaczony. W wojsku polskim Księstwa Warszawskiego zastosowano większość zasad organizacji armii francuskiej, uznawanej wtedy za wzór nowoczesnych sił zbrojnych. Wprowadzono w nim także zasadę awansu za zasługi i kompetencje, oficjalnie zniesiono hańbiące kary fizyczne. Znaczną wagę przykładano do budowania nowego typu morale wśród żołnierzy, którym starano się wpoić, że stanowią wspólnotę ludzi wolnych i równych. Doskonały przykład tego rodzaju zabiegów wychowawczych stanowi mowa wygłoszona w 1809 r. przez generała Maurycego Hauke do wziętych do niewoli Polaków z armii austriackiej, podejmujących służbę w szeregach polskiego wojska:

Kij zaś sromotny i wzgarda były całą dla was od Austriaków nagrodą. [--] Żołnierze! Już nikt was gnębić nie będzie bezkarnie, nikt się nad wami znęcać nie będzie. Wszyscy między sobą bracia jesteśmy i nie wyrzekamy się, jak tylko tchórzów i łotrów. [--] Dostąpić możecie, żołnierze, przez poświęcenie się Ojczyźnie i stanowi waszemu [--] tych zaszczytów i dobrodziejstw, jakie wielu waszym starszym braciom, jako i mnie, los wysłużyć pozwolił ${ }^{54}$.

W praktyce, także na tym polu szlachta podążała do awansu mniej wyboistą drogą. Zmiany stymulujące kariery nieszlachty były ograniczane przez relikty systemu klientalnego. Jego zasięg i siła to kwestia godna odrębnych badań prowadzonych na poziomie departamentów, powiatów, ale także pułków. Pozostaje jednak faktem, że to w armii Księstwa Warszawskiego ostatecznie ukształtował się nowoczesny model kariery oficera traktującego służbę wojskową nie tylko jako rodzaj obywatelskiego obowiązku, ale także zawód oraz sposób na awans w hierarchii wojskowej i społecznej. W latach 1807-1815 w gronie polskich generałów znalazły się dwie osoby o mieszczańskim rodowodzie, co stanowiło około 3 proc. całości grupy. W wywodzącej się z napoleońskich szeregów generalicji Królestwa Kongresowego i powstania listopadowego było ich już siedemnaście (15 proc.). Rozwiązaniem, które sprzyjało identyfikacji żołnierzy z armią, a w szerszym wymiarze - z państwem, było dopuszczenie ich przedstawicieli do komisji przedstawiających kandydatów do

${ }^{54}$ Cyt. za: W. Tokarz, Ksiaże Józef jako wychowawca wojska, w: idem, Rozprawy i szkice, t. 2: Militaria, Warszawa 1959, s. 312-313. 
odznaczenia krzyżem wojskowym Virtuti Militari i rad gospodarczych, nadzorujących administracyjno-gospodarczą stronę funkcjonowania pułków oraz opiniujących wnioski o awanse i urlopy.

Wydaje się, że we wskazanych przypadkach mamy do czynienia z sytuacją, gdy instytucje nowoczesnego państwa funkcjonują nie tylko jako narzędzia do sprawowania rządów, ale także sprzyjają procesom amalgamacyjnym, ułatwiając lub stymulując stopniowe zmiany w sferze struktury i mobilności społecznej oraz mentalności ${ }^{55}$. Tomasz Kizwalter zauważył, iż styl rządzenia niektórych dziewiętnastowiecznych przywódców o skłonnościach autorytarnych, m.in. Napoleona, skłaniał ich do szukania rozwiązań, które przybierały z czasem postać dobrze przemyślanych, długofalowych strategii i zaczynały przypominać to, co w XX w. zostało nazwane „inżynierią społeczną”. W owych próbach umacniania władzy dzięki „nawiązaniu kontaktu z masami” - choćby poprzez legitymizowanie jej za pomocą plebiscytów czy zwiększanie dostępu do praw wyborczych - dostrzegał on „niezależnie od demagogicznych akcentów i instrumentalnego traktowania kwestii społecznych, autentyczne nowatorstwo i dużo politycznej odwagi" 56 .

Sądzę, że niektóre spośród działań kręgów rządzących w Księstwie Warszawskim inspirowanych napoleońskimi wzorcami w pewnym stopniu wpisywały się w tendencję wskazaną przez Kizwaltera. W kręgach rządzących Księstwa Warszawskiego z pewnością nie dominowali radykalni nowatorzy. Warto jednak zwrócić uwage na podejmowane przez nie próby zwiększenia stopnia identyfikacji z państwem grup pozostających przedtem poza obrębem politycznej wspólnoty. Ciekawy przykład w tej mierze stanowi także akcja polityczna towarzysząca inicjatywie odbudowy Królestwa Polskiego w 1812 r. Przywódcy powołanej na sejmie Konfederacji Generalnej Królestwa Polskiego - związani z elitą władzy Księstwa lub lokalną elitą reprezentowaną przez posłów i deputowanych do Izby Poselskiej - swe działania legitymizowali, odwołując się do poparcia nie tylko sejmików, ale także zgromadzeń gminnych, gmin czy kahałów, które, składając akcesy do Konfederacji, zgłaszały swe poparcie dla politycznego planu odbudowy Królestwa Polskiego ${ }^{57}$. Akcja w znacznym stopniu odwoływała się do nawyków tkwiących w mentalności politycznej szlachty. Zarazem jednak dowodziła przekonania

${ }^{55} \mathrm{Na}$ rolę odgrywaną w tej mierze przez armię i instytucje państwowe zwrócił uwagę Tadeusz Łepkowski (Polska - narodziny nowoczesnego narodu 1764-1870, Poznań 2003, s. 145, 148).

56 T. Kizwalter, W stronę równości, Kraków 2014, s. 58.

57 P. Kubis, Nowoczesność czy tradycja? Konfederacja Generalna Królestwa Polskiego 1812 r., w: Studia nad epoka napoleońska, t. 2, red. M. Baranowski, Oświęcim 2016, s. 182-186, 188. 
rządzących, że w nowych warunkach politycznych należy zabiegać o jak najszerszą akceptację podejmowanych działań: „Wszyscy Polacy są wezwani i upoważnieni do wiązania się w Konfederację bądź pojedynczo, bądź łącznie" 58 .

Z pewnością nie należy przeceniać otwartości na zmiany większości ówczesnej polskiej elity politycznej. Historycy od dawna zwracali uwage na podejmowane w jej kręgu próby ograniczenia wpływu napoleońskiego ustawodawstwa na społeczeństwo zdominowane przez szlacheckich posesjonatów. O ograniczonej czy raczej - wybiórczej bądź specyficznie rozumianej gotowości do modernizacji świadczyło choćby wprowadzenie dekretu grudniowego (21 XII 1807), precyzującego zapisy konstytucji na niekorzyść chłopów, czy dekretu z 17 października 1808 r. zawieszającego na dziesięć lat prawa obywatelskie Żydów (zauważmy jednak, że aspirujące pod pewnymi względami do nowoczesności państwo pruskie nie podjęło szczególnych działań na rzecz ich „równouprawnienia”). Zarazem jednak, ówcześni zwolennicy „uobywatelnienia” Żydów mogli interpretować dekret jako część realizowanego przez państwo projektu modernizacyjnego - w tym przypadku zmierzającego do przyspieszenia asymilacji „mieszkańców wyznawających religię Mojżesza”.

Funkcjonowanie instytucji opartych na napoleońskich wzorcach bywało przedmiotem ostrej krytyki płynącej także z kręgów elity władzy. Zwykle formułowano ją ostrożnie, jednym z głośniejszych jej przykładów był opór powszechnie szanowanego Stanisława Małachowskiego przeciw wprowadzeniu Kodeksu Napoleona ${ }^{59}$. Akcentów krytycznych wobec skutków implementowania napoleońskich rozwiązań w Księstwie nie brakowało w raporcie radców stanu powołanych przez króla do wspomnianej już deputacji w celu „szukania sposobów wydoskonalenia systematu administracji”. Szkicując ponury obraz „upadku kraju”, deputacja wskazywała przede wszystkim problemy wynikające z nadmiernej liczby urzędników, która w tak małym kraju „przechodzi wszelką miarę, wszelkie znane w tym względzie stosunki, przechodzi więcej niż w trójnasób liczbę oficjalistów rządu austriackiego, któremu zbytnią ich mnogość za główną poczytywano wadę". Porównanie rozległości granic Francji i Księstwa Warszawskiego, ich poziomu rozwoju gospodarczego, dochodów skarbu, wreszcie liczby ludności i stopnia jej alfabetyzacji skłaniało deputację do wniosku, że z prostego przeniesienia wzorców francuskich na grunt polski wynikła „gwałtowna w niezliczonych biurach potrzeba rąk pisać

58 AGAD, Archiwum Zamoyskich, rkp. 85, Akt Konfederacji Generalnej, s. 3.

59 B. Szyndler, Stanisław Nałęcz Małachowski (1736-1809), Warszawa 1979, s. 311-312, 316-318. 
przynajmniej jako tako umiejących". Dodatkowo, niskie pensje w administracji odstręczały od pracy w niej „moralnych i zdatnych”, których miejsce zajmowali kandydaci o niższych kwalifikacjach zawodowych i etycznych. „Pasione tym [publicznym - J.C.] groszem nieznane nigdy w tym mnóstwie oficjalistów roje" nie zwiększały bynajmniej sprawności działania państwa, bowiem „kierunek z góry choćby najlepszy trafia w niższych szczeblach i ostatecznym wykonaniu na niezdolne narzędzia, na ludzi, którzy częstokroć nie są w stanie nie tylko wznieść się do zacności urzędowego powołania, lecz nawet wydanych sobie zrozumieć przepisów"60.

Co ciekawe, oceny stanu kraju ferowane przez związanych z elitą rządzącą radców stanu i referendarzy zbliżały się pod wieloma względami do opinii głoszonych przez opozycyjnych posłów ${ }^{61}$. Uważany za ich przywódcę Józef Godlewski w swej mowie wskazywał na szkodliwą skłonność rządzących do „naśladowania rządów państw wielkich i bogatych, do przejmowania od nich różnych cząstkowych urządzeń składających machinę, której ani części między sobą i ogółem, ani ogółu ciężar z siłą, która go ruszać ma, nie są w stosunku". Przesadnie rozbudowana administracja, szacowana przez posła na 9 tys. osób i zatrudniająca „wszystkich prawie pisać umiejących", rujnuje mieszkańców kraju i wprowadza stan urzędowej anarchii - obywatele nie potrafią poruszać się w gęstwinie nowych praw i instytucji, te zaś spętane są formalnościami oraz koniecznością wymiany korespondencji i wytwarzaniem akt, których liczba „W obłąkanie wprawuje samych twórców”. System deprawuje niedoświadczoną młodzież, która zasiadając na urzędach „nabiera opryskliwego tonu oraz chęci do oficjalskiego możnowładztwa [--]; a mieszkańce w przedpokojach skutków takich sentymentów doświadczać i cierpieć muszą"62.

Podobne oceny „urządzeń” zaprowadzonych w Księstwie znalazły się w adresie Izby Poselskiej do króla - Godlewski był zapewne jego głównym autorem. Obok przerostu rujnującej skarb biurokracji wskazano na równie szkodliwy dla państwa „labirynt praw [--] do naszego narodowego charakteru, gospodarstwa krajowego i stopnia cywilizacji niestosownych" i zbyt pospieszne - to oczywiście atak na ministra sprawiedliwości Łubieńskiego - wprowadzenie Kodeksu Napoleona bez

${ }^{60}$ Raport deputacji, k. 3, 9-10, 13v, 16, 23v, 67.

${ }^{61}$ Opinie deputacji oddawały poglądy jedynie części kręgów rządzących. Zawarta $\mathrm{w}$ raporcie krytyka systemu administracji wynikała m.in. również z napięć między Radą Stanu a Radą Ministrów będących rezultatem nadziei radców stanu na uzyskanie rzeczywistego wpływu na działania rządu (M. Mycielski, „Miasto ma mieszkańców, wieś obywateli", s. 69).

62 [J. Godlewski] Głos posła mariampolskiego dnia 17 grudnia 1811 r. na sejmie miany, w: idem, Głosy posła, s. 36, 53-54. 
przedłożenia urzędowego, dostosowanego do polskiej terminologii tłumaczenia i przygotowania instytucji sądowych do procedowania zgodnie z nowym prawem. Skutki owych posunięć to ogromne koszty działania administracji, brak kontroli nad przychodami i wydatkami państwa, ucisk fiskalny mieszkańców, rabunkowa gospodarka w dobrach narodowych, złe funkcjonowanie sądów, a przede wszystkim - otwarcie drogi praktyce rządzenia, która nasuwała skojarzenia z czasami kryzysu Rzeczypospolitej. Arbitralność rządzących, także administracji na szczeblach lokalnych pozbawionej faktycznie kontroli ze strony ciał samorządowych, skłaniała posłów do przekonania, że w nowych warunkach zaczynają działać dawne mechanizmy życia politycznego: „Wylęgła się już oligarchia, niebezpieczna z swych skutków dla tronu i mieszkańców. Powstała anarchia". Podobną ocenę sytuacji odnaleźć można w memoriałach przygotowywanych w tym czasie przez członka deputacji, referendarza Kajetana Koźmiana. Zauważał on, że realia funkcjonowania nowego ustroju nie czynią państwa sprawnym - przeciwnie, oddają je w ręce prawników i urzędników, co osłabia ducha obywatelskiego, poczucie więzi z państwem i grozi odrodzeniem się w nowej formie anarchii i pieniactwa ${ }^{63}$. To mocne stwierdzenie, zważywszy na rolę, jaką pojęcia te odgrywały w wyobraźni politycznej współczesnych.

Krytykę funkcjonowania instytucji państwa formułowaną w niektórych kręgach elity władzy i lokalnej elity politycznej, której reprezentanci zasiadali w Izbie Poselskiej, można uznać po części za świadectwo niechęci do zmian lub braku zrozumienia dla nich. Przykładem tego były przedstawione przez Godlewskiego propozycje oszczędności dla skarbu poprzez redukcję kosztów funkcjonowania wzorowanej na francuskiej administracji wojskowej. Zaproponowane przez posła zmiany - choćby przejęcie znacznej części obowiązków urzędników wojskowych przez oficerów sztabu głównego lub pułkowe rady gospodarcze, likwidacja odrębnych lazaretów zastąpionych przez pułkowe pod nadzorem pułkowników - być może doraźnie zmniejszyłyby obciążenia skarbu, ale w dłuższej perspektywie nie służyłyby raczej profesjonalizacji armii. O stosunku mówcy do nowych rozwiązań świadczyły również pojawiające się w jego wystąpieniu nawiązania do wzorów znanych z „taniej” armii przedrozbiorowej, choć tę trudno uznać za przykład nowoczesnych sił zbrojnych swojej epoki ${ }^{4}$. Niechęć części elity politycznej do modelu państwa opartego na scentralizowanej, rozbudowanej i kosztownej dla

${ }^{63}$ Adres Izby Poselskiej, w: ibidem, s. 7-8, 10-11; M. Mycielski, „Miasto ma mieszkańców, wieś obywateli", s. 64-65.

64 [J. Godlewski], Głosy posła, s. 62-64. 
skarbu administracji potwierdza debata toczona po abdykacji Napoleona w Komitecie Cywilnym Reformy powołanym przez Aleksandra I 19 maja 1814 r. W trakcie jego prac wyraźnie ujawniło się przekonanie części uczestników o konieczności nowej organizacji administracji, mniej kosztownej i dostosowanej do polskiej tradycji m.in. dzięki powrotowi do zasad kolegialności urzędów, wyborów części urzędników i przywrócenia bezpłatnych urzędów ${ }^{65}$.

Przytoczone powyżej przykłady krytyki funkcjonowania państwa i niektórych jego rozwiązań ustrojowych nie musiały wiązać się z pełną negacją systemu politycznego wprowadzonego przez napoleońską konstytucję. W Raporcie deputacji koncentrowano się na wadliwym działaniu instytucji państwa, nie kwestionowano jednak zalet francuskiego systemu organizacji administracji: „Deputacja doskonałości urządzeń francuskich nie uwłacza i w ogólnym wzięciu nie przeciwi się ich naśladowaniu, sądzi owszem, iż w te piękne wzory wpatrywać się, nigdy ich z oka i z baczenia nie spuszczać i do nich ciągle zbliżać się należy, lecz sądzi także, iż za każdym w tej mierze krokiem godzi się pilnie ważyć na szali z jednej strony ich pożytki, z drugiej do ich przyjęcia sposobność". Napoleon, stwierdzano, zdawał sobie sprawę, że Księstwo Warszawskie potrzebuje ,administracji jak najbardziej usymplikowanej, jak najmniej kosztownej", dlatego też określił jedynie ogólne zasady jej organizacji. Błędy popełniono na etapie rozwijania lakonicznych zapisów konstytucji: „teoretycznie chwalebna chęć” naśladownictwa doskonałego ustroju napoleońskiej Francji „uniosła nas tak daleko, żeśmy na domowe niedostatki, na niedoskonałość i ludu, i kraju naszego własnego obejrzeć się zaniedbali". W efekcie stworzono system na pozór wzorowany na napoleońskim, ale w warunkach polskich niefunkcjonujący równie sprawnie, niedostosowany do potrzeb i możliwości kraju - autorom raportu przypominał on człowieka, któremu troskliwie założono „płaszcz równie świetny, jak wygodny, pod nim szaty i dostatnie, i ciepłe, lecz włożono razem koszulę ostrą, grubą, brudem i robactwem zeszpeconą; cóż mu więc płaszcz i szaty pomogą, kiedy odzież samego dotykająca ciała ustawne gryzie, drażni i szkodliwych chorób udziela zarody?"66. Uznając korzyści płynące z podstawowych napoleońskich zasad ustrojowych, choćby centralizacji władzy, deputacja postulowała wyraźne rozgraniczenie kompetencji ministrów, uproszczenie procedur, redukcję administracji

65 J. Przygodzki, Rada Najwyższa Tymczasowa Księstwa Warszawskiego 1813-1815, Wrocław 2002, s. 179-196, 202; M. Mycielski, Rząd Królestwa Polskiego wobec sejmików i zgromadzeń gminnych 1815-1830, Warszawa 2010, s. 32, 36, 38; T. Kizwalter, Kryzys oświecenia a początki konserwatyzmu polskiego, Warszawa 1987, s. 73-77.

${ }^{66}$ Raport deputacji, k. 8, 22, 24-25. 
i dostosowanie systemu podatkowego do potrzeb i możliwości kraju. Wskazywała również na konieczność podniesienia stopnia oświecenia obywateli, bowiem, „do tych praw tak doskonałych my jeszcze dosyć doskonałymi nie jesteśmy"67.

Podobną ocenę funkcjonowania wielu napoleońskich rozwiązań ze sfery prawa i instytucji odnaleźć można w mowie Godlewskiego i adresie Izby Poselskiej do króla. Poseł mariampolski w swym wystąpieniu podkreślił dobrodziejstwa, jakich dostąpiło Księstwo dzięki „Mądremu Prawodawcy”, zaliczając do nich: monarchę, „któregośmy zawsze sobie życzyli”, konstytucję zapewniającą wolność chłopów, parlament „reprezentujący naród i stanowiący w imieniu mieszkańców prawa i podatki”, rady departamentowe, powiatowe i municypalne „obowiązane radzić i działać dla polepszenia losu kraju i mieszkańców", niezawisłe sądy, „elekcję niektórych urzędników” oraz własną armię. Godlewski wyraźnie zaznaczył również korzyści płynące z kluczowej w napoleońskiej konstytucji zasady: „rząd jest w osobie króla”, która odsuwała zagrożenie powrotu kryzysu państwa z czasów przedrozbiorowych: „Mamy skoncentrowany rząd w jednej osobie panującego, położoną tamę możnowładztwu, arbitralności, zgubom i nieporządkowi z rozdzielenia władzy rządowej zwyczajnie u nas doświadczanym"68. Mocna deklaracja uznania dla głównych zasad napoleońskiego systemu ułatwiała posłowi krytykę sposobu, w jaki wprowadzono je w życie. Napoleon - stwierdzał - nakreślił w konstytucji jedynie najważniejsze ramy ustrojowe państwa, nie precyzując szczegółów organizacji jego instytucji, stosowanych przez nie procedur, granic kompetencji ministrów, liczby urzędników czy kosztów utrzymania armii, uznając, że „przepisanie tego wszystkiego do charakteru i ducha mieszkańców, do okoliczności i położenia kraju zastosowane być powinno". Zasady tej nie przestrzegali polscy współpracownicy Fryderyka Augusta, przyczyn narastającego kryzys państwa należy zatem upatrywać w „niedopełnieniu niektórych, niedokładnemu dopełnieniu i przepełnieniu niektórych artykułów Statutu". Środki zaradcze zaproponowane przez opozycyjnego posła były zbieżne z postulatami zgłoszonymi w znanym mu z pewnością Raporcie deputacji - reorganizacja administracji i zmniejszenie jej kosztów, rozgraniczenie kompetencji ministrów, zmiany w systemie podatkowym, częściowy powrót do bezpłatnych urzędów obsadzanych przez właścicieli ziemskich: „Róbmy ekonomicznie i po narodowemu" ${ }^{6}$. Mowa Godlewskiego rozwijała myśli

${ }^{67}$ Ibidem, k. 8, 123.

68 [J. Godlewski], Głosy posła, s. 35.

69 Ibidem, s. 35-37, 72. 
zawarte w złożonym kilka dni wcześniej adresie Izby Poselskiej do króla. Do wspólnych wątków obu wystąpień należały: uznanie wartości napoleońskich zasad ustrojowych, konieczność modyfikacji sposobu, w jakie wprowadzono je w życie oraz ostra krytyka „pierwszych urzędników” Księstwa podsuwających królowi projekty dekretów, które zamiast rozwijać artykuły konstytucji zgodnie z możliwościami i potrzebami obywateli, „uczyniły mieszkańca w swym kraju obcym, zniszczyły jego bezpieczeństwo i spokojność co do osoby i majątku"70.

Przewijające się w Raporcie deputacji, adresie Izby Poselskiej i mowie Godlewskiego wyrazy podziwu dla napoleońskiego ustawodawstwa miały po części wymiar taktyczny - doskonałości praw nadanych przez „wskrzesiciela” nie można było oficjalnie kwestionować. W propozycjach przedstawionych przez deputację zwraca jednak uwagę przekonanie, że powrót do niektórych instytucji i rozwiązań przedrozbiorowych byłby korzystny nie tylko $\mathrm{z}$ uwagi na zmniejszenie wydatków państwa i usprawnienie działań jego instytucji. Sprzyjałby również umocnieniu ducha narodowego - jego właściwym depozytariuszem jest zaś warstwa szlacheckich posesjonatów stanowiąca esencję narodu. Za postulatem „zachowania i pielęgnowania charakteru narodowego" kryło się sporo nostalgii za ustrojem trzeciomajowym. Deputacja wysoko zatem oceniła dorobek Sejmu Wielkiego, który „oddał hołd równym prawej wolności i dobrego rządu wyobrażeniom"71.

Żywe wśród części elity politycznej przekonanie, że Konstytucja 3 maja pozostaje wzorcem ustrojowym, najlepiej odpowiadającym potrzebom kraju, budziła niepokój środowisk, które wyżej ceniły rozwiązania prawno-ustrojowe Księstwa Warszawskiego. Wydaje się, że sięgnął on apogeum w pierwszych tygodniach wojny z Rosją w 1812 r. Jego wyrazem była m.in. broszura opublikowana przez deputowanego Ignacego Stawiarskiego, w której znalazły się zawoalowane ostrzeżenia przed „samolubcami” dążącymi do obalenia konstytucji Księstwa. Nie były one pozbawione podstaw - krytyczny wobec napoleońskich wzorców wicemarszałek Konfederacji Generalnej Stanisław Zamoyski, prowadząc wówczas w Wilnie rozmowy z francuskim ministrem sekretarzem stanu Maretem przekonywał, że ustrój Królestwa Polskiego odbudowanego dzięki zwycięstwu Napoleona powinien w większym stopniu odwoływać się do Ustawy Rządowej. Pod wpływem wieści o nich, minister sprawiedliwości Łubieński, gorący zwolennik napoleońskich rozwiązań, alarmował ministra sekretarza stanu Stanisława Brezę, że propozycje Zamoyskiego grożą

\footnotetext{
70 Adres Izby Poselskiej w: ibidem, s. 6, 12.

${ }^{71}$ Raport deputacji, k. 10v-12v.
} 
powrotem „przemocy arystokratycznej” i likwidacją zasady „równości praw dla wszystkich mieszkańców"72.

Krytyki funkcjonowania instytucji państwa oraz postulatu sięgnięcia do polskiej tradycji w zakresie jego organizacji nie należy jednak interpretować wyłącznie jako wyrazu zakamuflowanego dążenia do obalenia napoleońskiego ustroju. Trudno jednoznacznie ocenić intencje, jakimi kierowali się wszyscy krytycy napoleońskiego ustroju w Księstwie. Wydaje się jednak, że wielu z nich rzeczywiście akceptowało jego najważniejsze rozwiązania, wskazując na konieczność zaprowadzenia „odmian” dostosowujących go do lokalnych warunków. Krytykom nie sposób przy tym odmówić pewnego realizmu w ocenie sytuacji. Część ich argumentów, choćby dotyczących zawyżonych kosztów funkcjonowania administracji, jej nadmiernej liczebności i trudności z uzupełnianiem kadr wynikających z niewielkiej nadal liczby wykształconych kandydatów, można uznać za przekonujące. Postulat powrotu do niektórych, „ekonomicznych i narodowych" rozwiązań miał jednak wymiar nie tylko pragmatyczny. Kryła się za nim także chęć zatrzymania lub opóźnienia nieuniknionego w systemie napoleońskim spadku politycznego znaczenia szlacheckich posiadaczy ziemskich.

Owo uznanie wywodzącej się ze szlachty elity politycznej dla przynajmniej części nowych zasad ustrojowych, choćby silnej władzy monarchy, połączone z chęcią utrzymania własnej politycznej i społecznej pozycji, wydaje się dobrze oddawać specyfikę państwa, jakim było Księstwo Warszawskie. W praktyce politycznej dobrze ilustruje ją paradoksalne połączenie zasady równości wobec prawa z zachowaniem odrębnych kolegiów wyborczych dla szlachty oraz różna tytulatura członków Izby Poselskiej wybieranych na sejmikach i zgromadzeniach gminnych. Zasiadający w niej posłowie i deputowani mieli jednak takie same prawa. Reprezentanci nieszlachty lub szlachty nieposiadającej majątków ziemskich uzyskali w tej mierze więcej, niż plenipotentom miast królewskich przyznawała Konstytucja 3 maja. Z tego m.in. względu Joachim Lelewel stwierdzał, że ustrój Księstwa Warszawskiego zachowywał „tylko kolor stanów". Z górą sto lat później podobnym tropem podążył Bogusław Leśnodorski, podkreślając znaczenie, jakie dla przemian społecznych dokonujących się w tej części ziem polskich w XIX w. miały instytucje ustrojowe i prawne wprowadzone w Księstwie Warszawskim. W jego ujęciu przekroczono wówczas „próg nowego stulecia” - w istocie,

72 M. Mycielski, „Miasto ma mieszkańców, wieś obywateli”, s. 107-110; M. Handelsman, Projekt zmiany konstytucji z r. 1812, w: idem, Pod znakiem Napoleona. Studia historyczne, seria 2, Warszawa 1913, s. 200-203. 
próg nowoczesności. Podobne oceny formułowała Barbara Grochulska w swej monografii napoleońskiego protektoratu nad Wisłą. U schyłku lat siedemdziesiątych ubiegłego wieku Jerzy Jedlicki ostrożnie pytał, czy społeczeństwo stanowe dostosowało się po 1807 r. „do prawie już bezstanowego prawa”, czy też raczej dopasowało je do siebie. Porównanie modelu ustrojowego Księstwa Warszawskiego z jego realiami społecznymi i politycznymi potwierdzało, jego zdaniem, trafność opinii Lelewela. Współcześnie, wyraźny wpływ istniejących w Księstwie uwarunkowań ustrojowych na długofalowe przemiany społeczne na ziemiach polskich podkreśla Kizwalter. Opinie historyków prawa i instytucji oddaje stwierdzenie Kallasa, który w ustroju Księstwa dostrzega „etap organizacyjny w procesie tworzenia się nowoczesnej państwowości polskiej w epoce porozbiorowej"73.

Powyższe refleksje warto uzupełnić o jeszcze jedną perspektywę. Za jedno z kryteriów nowoczesności państwa można uznać także gotowość do podejmowania inicjatyw wykraczających poza sprawne zarządzanie zastaną rzeczywistością społeczną, gospodarczą i polityczną. W nowoczesnym lub aspirującym do nowoczesności państwie kręgi rządzące lub przynajmniej ich część uznają potrzebę prowadzenia działań uzgodnionych z pewnym projektem ideologicznym i stymulujących, choćby w długiej perspektywie, zmiany w zakresie struktury społecznej, mentalności, społecznej emancypacji poszczególnych grup, ale także przemian cywilizacyjnych ${ }^{74}$. Kryterium to zbliża się pod tym względem do wspomnianej przez Habermasa zdolności państwa do stymulowania lub wspierania nowej integracji kulturowej zamieszkującej je zbiorowości. Ustrój w Księstwie Warszawskim i znaczna część działań podejmowanych w jego ramach przez rządzących sprzyjały przemianom modernizującym państwo i osłabiającym działanie dawnych barier stanowych dzielących dotąd społeczeństwo. Nie wszystkie jednak podejmowano z zapałem. W przypadku niektórych inicjatyw można dostrzec dążenie do ograniczenia zasięgu wywołanych przez nie zmian. Czy kręgi rządzące Księstwem chciały „być nowoczesne”, czy też ulegały pod tym względem presji ze strony Napoleona?

73 J. Lelewel, Trzy konstytucje polskie 1791, 1807, 1815, w: idem, Dzieła, t. 8, oprac. J. Dutkiewicz [et al.], Warszawa 1961, s. 533; B. Leśnodorski, U progu nowego stulecia. Księstwo Warszawskie, w: idem, Historia i współczesność, Warszawa 1967, s. 212; B. Grochulska, Księstwo Warszawskie, s. 89, 92; J. Jedlicki, Szlachta, w: Przemiany społeczne w Królestwie Polskim 1815-1864, red. W. Kula, J. Leskiewiczowa, Wrocław 1979, s. 30; T. Kizwalter, W strone równości, s. 108; M. Kallas, Historia ustroju Polski, s. 200.

${ }^{74} \mathrm{Za}$ inspirujące dyskusje nad tą kwestią dziękuję Tomaszowi Kizwalterowi oraz Maciejowi Mycielskiemu. 
Warto zauważyć, że cytowana we wstępie odezwa Dyrektorium Generalnego z 1807 r. przedstawiała rodakom korzyści płynące z utworzenia Księstwa Warszawskiego jeszcze w dość tradycyjnych kategoriach - podkreślając przywrócenie praw języka polskiego, powrót na tron dawnej dynastii czy przywołując tradycję wielkich „naddziadów”. W ówczesnej mentalności politycznej nie funkcjonowało jeszcze pojęcie nowoczesności. Opisywano ją raczej intuicyjnie, jako przeciwieństwo „nieczynności”, czyli zacofania i zastoju, lub - w sferze polityki - osiemnastowiecznych plag: „anarchii”, „bezrządu”, „ducha fakcji”. Analiza wyobrażeń przynajmniej części kręgów rządzących na temat zadań stojących przed państwem skłania jednak do przekonania, że wielu ich przedstawicieli miało poczucie potrzeby działań na rzecz niezwerbalizowanej jeszcze nowoczesności. Do refleksji skłania również casus Łubieńskiego. Minister sprawiedliwości, jeden z promotorów dekretu grudniowego, w $1812 \mathrm{r}$. przedstawił królowi własne uwagi do projektu konstytucji Królestwa Polskiego, wywiedzione, zdaniem Handelsmana, z głębokiego zrozumienia idei napoleońskich: „Nie liberalne, lecz demokratyczne, przeciwne wolności indywidualnej, przepojone duchem ześrodkowanego urzędniczego państwa, [--] lecz opierające się na zasadzie równości obywatelskiej wobec prawa i pociągnięcia szerszych mas narodowych do czynnego życia publicznego"75. Przypadek ów skłania do wniosku, że w ówczesnej mentalności elity politycznej istniało także coś na kształt gotowości do „wybiórczej” lub stopniowanej modernizacji.

Interesujący jej przykład stanowi, według mnie, Raport deputacji powołanej przez króla do przedstawienia uwag na temat udoskonalenia systemu administracyjnego i podatkowego „tudzież na wszystkie przedmioty do wzrostu kraju przyczynić się zdolne". Jedną z jego części zatytułowano zatem: „Myśli względem wzrostu kraju”. Jak zauważył Leśnodorski, zastosowanie tego pojęcia, przeciwstawionego zacofaniu, można uznać za przykład otwarcia na nowe idee ${ }^{76}$. Nowoczesność, jeszcze nienazwana, wyraźnie pojawiała się w podsumowaniu dokumentu. Jego autorzy podkreślali, że szukając sposobów poprawy sytuacji państwa, deputacja „nie spuściła [--] z baczności swojej ani wieku, w którym żyjemy, ani ducha, w którym się dzisiejsze przekształcają społeczeństwa”. Deputacja wzięła to pod uwagę, „wiedząc, iż postępować z wiekiem i dążenia powszechnego być z godnością i z rozsądkiem uczestnikami, nie jest obcą dla ludzi publicznych powinnością". Zrozumienie dla wymogów nowoczesności (opisanych jako „bystre czynnego wieku światła”) łączyło

${ }^{75}$ M. Handelsman, Projekt zmiany konstytucji, s. 204-212.

76 B. Leśnodorski, U progu nowego stulecia, s. 211. 
się z przekonaniem, że - zwłaszcza w epoce wielkich i nagłych zmian celem rządzących powinno być także „szczęście” narodu oraz „zachowanie i pielęgnowanie charakteru narodowego, dawnych cnót, szlachetnych obyczajów, szanownych uczuciów, słowem tego, co w narodowości każdego społeczeństwa najcelniejszym być może". Wpływu tradycji nie należy lekceważyć, bowiem „wszędzie natura i czas tak ważne i wyraźne na ludziach położyły znamiona, iż wygładzać ich bez szkody wielu pokoleń ani można, ani potrzeba, ani się godzi"77.

Autorzy raportu dostrzegali konieczność zmian zgodnych z „wiekiem i dążeniem powszechnym”, choć ich zasięg i tempo miały być regulowane przez konserwatywny szacunek dla tradycji. Raport przedstawiał jednak ogromne oczekiwania wobec państwa. Za niezbędny warunek wzrostu kraju, rozumianego jako całokształt zmian w sferze gospodarki i relacji społecznych, uznano „pomoc materialną i moralną” ze strony rządu. Pierwsza miała wspomóc w pokonaniu barier ograniczających rozwój kraju, którymi były: niewielka liczba ludności, brak kapitału oraz „brak właścicieli w klasie więcej zapewne jak połowę gruntu rolnego w całym kraju posiadającej".

By poprawić sytuację demograficzną kraju, rząd powinien zatem zapobiegać emigracji, rozpoznając przyczyny, które skłaniają do niej różne grupy ludności, i usuwając je. W przypadku „klasy cudzoziemskich fabrykantów" oznaczałoby to np. zwolnienie ich od obowiązku wojskowego kwaterunku czy zabezpieczenie przed prześladowaniami spowodowanymi „podejrzeniami przeciw cudzoziemcom” (skądinąd, uznanymi za „poniekąd usprawiedliwione”). Ucieczkom chłopów podczas konskrypcji zapobiegać miały działania edukacyjne, zmniejszające obawy przed służbą wojskową przedstawianą jako powszechny obowiązek, nie zaś formę zemsty „zwierzchności dworskiej”. Jednocześnie rząd powinien wspierać napływ imigrantów, śledząc sytuację w krajach ościennych, by „przywabić każdą klasę właściwą dla niej przynętą”, oferując okresowe zwolnienia od podatków i obowiązku służby wojskowej czy ułatwiając zakładanie nowych manufaktur. Władze powinny również troszczyć się o przyrost naturalny, podejmując działania na rzecz zmniejszenia śmiertelności przez obowiązkowe szczepienia dzieci, propagowanie zasad higieny i dietetyki oraz wzrostu liczby narodzin. Wśród sposobów zmierzających ku temu wskazywano na konieczność prowadzenia przez państwo swego rodzaju polityki prorodzinnej poprzez działania zachęcające do zawierania małżeństw i zakładania nowych gospodarstw (np. przez okresowe zwolnienia od podatków), podwyższenie podatku

77 Raport deputacji, k. 264. 
osobistego dla bezżennych czy nagradzanie „hodowania dzieci” przez ulgi podatkowe oraz dodatkowe wsparcie dla rodziców wychowujących przynajmniej sześcioro dzieci ${ }^{78}$.

Brakowi kapitału zaradzić miał rząd, regulując stan prawny własności w kraju (np. przeprowadzając ostateczne rozgraniczenie gruntów i opracowując „przepisy hipoteczne”), wprowadzając system zachęt podatkowych dla cudzoziemców gotowych rozpocząć działalność handlową lub przemysłową w Księstwie czy podejmując liczne przedsięwzięcia poprawiające stan infrastruktury kraju (planowa rozbudowa głównych dróg, budowa mostów, regulacja rzek przez sprowadzonych z zagranicy specjalistów, założenie szkoły inżynieryjnej). Kumulacji kapitału służyć miał również stymulowany lub popierany przez rząd rozwój produkcji i handlu. Proponowane działania obejmowałyby finansowanie prowadzonych przez fachowców wzorcowych gospodarstw rolnych „zapomożonych” w najlepsze gatunki zwierząt hodowlanych, zbóż i warzyw, doskonale zaopatrzonych w narzędzia, które pełniłyby rolę ośrodków edukacyjnych dla rolników i punktów sprzedaży „tego wszystkiego, co im do polepszenia gospodarstwa będzie potrzebne". Rząd powinien również troszczyć się o poprawę obrotu towarowego, odpowiednio kształtując politykę celną i tworząc sieć lokalnych jarmarków „na różne produkta”"

Interesująco rysowała się propozycja „pomocy materialnej” rządu w kwestii przemian własności ziemi rolnej. Deputacja zbliżyła się w tym względzie do opinii Surowieckiego, który zwracał uwagę, że bez nadania chłopu własności uprawianej ziemi „nie należy się po nim spodziewać ani wielkiego patriotyzmu, ani gorliwości o dobro powszechne, ani wygórowania przemysłu, ani też kultury i moralności" ${ }^{80}$. W raporcie wyraźnie stwierdzono konieczność doprowadzenia przez rząd do stanu, by w dobrach narodowych „ta część gruntów, która dla włościan jest przeznaczona, stała się ich własnością". Za przykładem rządu podążyć mieli szlacheccy posesjonaci. Zakrojona na dużą skalę operacja miała rozpocząć się od rozgraniczania działek i wyznaczenia ich „przyzwoitej” wielkości oraz ustanowienia kasy zapomogowej zmniejszającej wydatki właścicieli na koszty wyodrębnienia chłopskich gruntów, włościanom zaś umożliwiającej pokrycie kosztów nabycia własności. Część funduszy na organizację kasy miała pochodzić ze skarbu, większość... od dłużników sum bajońskich (należy jednak dodać, że deputacja domagała się zdecydowanego ich zdyscyplinowania, co miało znacząco zwiększyć wpływy

78 Ibidem, k. 242-244.

${ }^{79}$ Ibidem, k. 245-249, 252.

${ }^{80}$ W. Surowiecki, op. cit., s. 448. 
ze spłat zadłużenia) ${ }^{81}$. Wydaje się, że projekt nawiązywał do dyskusji na temat uwłaszczenia chłopów w dobrach narodowych toczonej w Radzie Stanu w $1808 \mathrm{r}^{82}$, skala proponowanych działań była jednak większa.

Oczekiwana przez deputację „pomoc moralna” ze strony rządu miała z kolei usunąć bariery wzrostu stwarzane przez „nieoświecenie, gnuśność i pijactwo ludu pospolitego". Uznawszy, że „ciemnota” ludu wiejskiego nie jest skutkiem „wstrętu jego do nauki”, lecz braku możliwości edukacyjnych, autorzy raportu przedstawili rozbudowany program rozwoju szkolnictwa elementarnego, uwzględniający kształcenie nauczycieli oraz motywowanie (także finansowe) uczniów w celu rozbudzenia w nich „szlachetnej emulacji”. W zwalczanie „gnuśności i pijactwa” angażować mieli się duchowni, nauczyciele, lokalne władze administracyjne oraz rady powiatowe, oddziałując na chłopów poprzez przykład specjalnych, wzorcowych gospodarstw, czasopism „, przypowieściami umoralniającymi, przepisami higieny, dietetyki i postrzeżeniami gospodarskimi do pojęcia ludu wiejskiego przystosowanymi" oraz system nagród dla najlepszych gospodarzy. Ogromne oczekiwania kierowano pod adresem duchowieństwa, które niejako przy okazji powinno przejść „reformę”, dzięki której poprawiony zostanie proces selekcji kandydatów, wprowadzony kurs świeckich nauk w seminariach oraz ograniczona liczebność uznanego za bezużyteczne „zakonnictwa”. W dokumencie powracał również przewijający się już w debatach prowadzonych w czasach przedrozbiorowych wniosek, że skuteczna walka z pijaństwem na wsi jest niemożliwa bez zakazania Żydom produkcji i sprzedaży alkoholu. Doraźnie proponowano przywrócić dawne zarządzenie pruskie, umożliwiające umorzenie zbyt wysokich długów zaciągniętych w karczmie ${ }^{83}$.

Działania rządu na rzecz „wzrostu kraju”, z których część wyraźnie wzorowano na praktykach rządów pruskich, obejmować miały również „polepszenie losu miast” uwolnionych od obowiązku kwaterunkowego dzięki budowie koszar, a nim to nastąpi - likwidacji mniej licznych zgromadzeń zakonnych i zajęciu należących do nich zabudowań. Od rządu oczekiwano także działań na rzecz poprawy jakości życia w miastach. Miały one, począwszy od Warszawy, rozwiązać kwestie higieny i porządku w przestrzeni publicznej oraz regulować sferę określoną później jako ład przestrzenny poprzez wytyczanie nowych ulic i placów targowych, określenie ich wymiarów czy ustalenie wielkości stojących przy nich domów.

${ }^{81}$ Raport deputacji, k. 249v-251.

${ }^{82}$ H. Grynwaser, Kwestia agrarna i ruch włościan w Królestwie Polskim w pierwszej połowie XIX w. Studium archiwalne, Warszawa 1935, s. 38-40.

${ }^{83}$ Raport deputacji, k. 253-260. 
Ów sui generis plan zagospodarowania przestrzennego miast uwzględniać miał również wyznaczenie stref osiedlenia dla Żydów ${ }^{84}$.

Można przypuszczać, że znaczną część postulatów zawartych w tej części raportu przyjęto pod wpływem zasiadającego w deputacji referendarza Staszica. Fakt, że pozostali jej członkowie zaakceptowali założenie, iż do obowiązków władz państwowych należy wspieranie działań zmierzających do przyspieszenia rozwoju cywilizacyjnego kraju, uważam za znaczący przykład nowoczesnych oczekiwań wobec państwa formułowanych w gronie elity rządzącej - bo za taką można uznać referendarzy i radców stanu. Owo nastawienie, dostrzegalne także w głosach posłów dowodzi, że w środowisku elity politycznej Księstwa Warszawskiego istniały kręgi gotowe na nowoczesność - nawet jeśli różniły się pod względem wyobrażeń na temat jej kształtu, zakresu zmian i ich tempa. Tworzyło to też pewną tradycję myślenia o państwie, które nie tylko konserwuje, ale też aktywnie działa na rzecz zmian.

Zdecydowanej większości postulatów deputacji nie udało się zrealizować, niektóre podjęto w dobie Królestwa Polskiego. Mimo to sądzę, że Księstwo Warszawskie należy uznać za pierwsze nowoczesne państwo polskie. Była to nowoczesność podlegająca ograniczeniom - wyraźniej obecna w obszarze ustroju i instytucji, w sferze zaś ich funkcjonowania czy społecznych i politycznych praktyk w pewnym stopniu modelowana przez nawyki utrwalone w mentalności politycznej szlachty, utrudniające pełną i szybką implementację napoleońskich wzorców prawno-ustrojowych. W pewnym stopniu spowalniały ją również społeczne i cywilizacyjne realia, w jakich miały one funkcjonować.

Sporządzając bilans dokonań państwa w latach 1807-1812 warto zauważyć, że okres jego normalnego, pokojowego funkcjonowania wyniósł - po odliczeniu około czterech miesięcy oczekiwania na decyzje króla w sprawie organizacji najwyższych urzędów i około trzech miesięcy wojny z Austrią w 1809 r. - niecałe pięć lat. Skalę działań państwa dodatkowo ograniczały ogromne trudności finansowe spowodowane w dużej mierze kosztami utrzymania armii, rozbudowy twierdz i przygotowań do wojny 1812 r. W tym kontekście łatwo zrozumieć przyczyny, dla których posłowie stwierdzali w adresie do króla, iż w 1811 r. Księstwo Warszawskie „nie wyszło jeszcze z początkowego zamieszania”.

Państwo podejmowało jednak działania, które były znakami nowoczesności. „Próg nowego stulecia”, o którym pisał Leśnodorski, został

${ }^{84}$ Ibidem, k. 260-261v. 
przekroczony. Była to zapewne nowoczesność na miarę epoki i realiów społecznych, politycznych i kulturowych tej części Europy. Mimo to, a może właśnie dlatego, owe działania podejmowane zgodnie z „duchem, w którym się dzisiejsze przekształcają społeczeństwa” zasługują na szczególne uznanie.

\section{Streszczenie}

Artykuł dotyczy kwestii nowoczesności ustroju, instytucji państwowych i życia politycznego w Księstwie Warszawskim (1807-1815). Autor przyjmuje, że najważniejszymi cechami nowoczesnego państwa są: zdolność do skoordynowanej kontroli nad obszarami, które obejmuje oraz do stymulowania nowej integracji kulturowej związanej z rodzącą się świadomością narodową zamieszkującej je zbiorowości. Za istotne kryterium nowoczesności uznaje również gotowość elity rządzącej do podejmowania inicjatyw promujących przemiany cywilizacyjne czy zmiany w zakresie struktury społecznej i mentalności.

Autor, szukając odpowiedzi na pytanie, czy Księstwo Warszawskie było pierwszym nowoczesnym państwem polskim, odwołuje się do wcześniejszych ustaleń historyków. Analizuje wpływ, jaki na jego ustrój wywarły tradycje Ustawy Rządowej z 1791 r., wzorce pruskie i rozwiązania francuskie zawarte w nadanej przez Napoleona konstytucji Księstwa. Wskazuje na dokonujące się u schyłku XVIII i w początkach XIX w. przemiany mentalności politycznej znacznej części polskiej elity, które umożliwiły jej akceptację ustroju politycznego Księstwa, choć odbiegał on od tradycji Konstytucji 3 maja. Analizuje również pojawiające się w źródłach oczekiwania wobec państwa formułowane w kontekście znanego już w czasach przedrozbiorowych dyskursu modernizacyjnego oraz głosy krytyczne na temat funkcjonowania administracji Księstwa, opartej na wzorcach scentralizowanego państwa napoleońskiego.

Konfrontacja wzorców prawno-ustrojowych z realiami ich funkcjonowania $\mathrm{w}$ otoczeniu społecznym ukształtowanym $\mathrm{w}$ warunkach ustroju stanowego oraz działaniami podejmowanymi przez rządzących prowadzą do wniosku, że Księstwo Warszawskie należy uznać za pierwsze nowoczesne państwo polskie, choć była to nowoczesność podlegająca ograniczeniom. Wyraźniej była obecna w obszarze ustroju i instytucji, zaś w sferze ich funkcjonowania czy społecznych i politycznych praktyk w pewnym stopniu modelowały ją nawyki utrwalone w mentalności politycznej szlachty, utrudniające pełną i szybką implementację napoleońskich wzorców prawno-ustrojowych. Spowalniały ją również społeczne i cywilizacyjne realia, w jakich wspomniane wzorce miały funkcjonować.

\section{The Duchy of Warsaw - the First Modern Polish State?}

The article deals with the question of the modernity of the political system, state institutions, and political life of the Duchy of Warsaw (1807-1815). The author argues that the main features of the modern state are the capacity to exercise 
coordinated control over its territory and to stimulate a new cultural integration resulting from the developing national awareness of the inhabitants. They also include the willingness of the ruling elite to undertake initiatives promoting civilizational transformations and changes in the social structure and mentality recognized as important criteria of modernity.

In trying to answer the question whether the Duchy of Warsaw was the first modern Polish state, the author draws on previous studies of the subject. He analyses the impact on its political system made by the traditions of the Constitution of 3 May 1791, Prussian models, and French solutions that were included in the constitution of the Duchy imposed by Napoleon. He indicates changes in political mentality of a large part of the Polish elites which occurred in the late eighteenth and early nineteenth century and made it possible for them to accept the political system of the Duchy despite its differences from the tradition of the Constitution of 3 May. He also analyses expectations present in sources formed in the context of modernization discourse known before the partitions, and critical voices on the functioning of the Duchy's administration modelled on the centralized Napoleonic state.

Confrontation of legal and political models with the reality of their functioning within the social environment shaped by the conditions of estate divisions and actions undertaken by the authorities leads to the conclusion that the Duchy of Warsaw should be regarded as the first Polish modern state, although it was of limited modernity. More visible in the sphere of political system and institutions, modernity was restricted in the area of their operations or social and political practices, where it was modelled on habits developed in the political mentality of the nobility, which hampered a swift and full implementation of Napoleonic legal and political models. To a certain extent, it was slowed down also by the social and civilizational realities in which those models were to operate.

Translated by Grażyna Waluga

\section{Bibliografia}

Cichoń Paweł, Rozwój myśli administracyjnej w Księstwie Warszawskim 1807-1815, Księgarnia Akademicka, Kraków 2006.

Collaboration and Resistance in Napoleonic Europe. State-Formation in an Age of Upheaval, c. 1800-1815, red. Michael Rowe, Palgrave, Basingstoke-New York 2003.

Czubaty Jarosław, Księstwo Warszawskie 1807-1815, Wydawnictwo Uniwersytetu Warszawskiego, Warszawa 2011.

Czubaty Jarosław, Zasada „dwóch sumień”. Normy postępowania i granice kompromisu politycznego Polaków w sytuacjach wyboru (1795-1815), Neriton, Warszawa 2005.

Gałędek Michał, Miejsce resortu spraw wewnętrznych w administracji Księstwa Warszawskiego, „Krakowskie Studia z Historii Państwa i Prawa” 6 (4), 2013, s. 405-422.

Giddens Anthony, Konsekwencje nowoczesności, Wydawnictwo UJ, Kraków 2008.

Goclon Jacek A., „Polska na królu pruskim zdobyta”. Ustrój, administracja i sądownictwo doby Komisji Rządzacej w 1807 r., Wydawnictwo Uniwersytetu Wrocławskiego, Wrocław 1999. 
[Godlewski Józef], Głosy posła mariampolskiego na sejmie roku 1811 w Warszawie miane $z$ dołaczeniem uwag i krótkiego namienienia niektórych w czasie sejmu czynności, Drukarnia Rządowa, Warszawa 1814.

Grochulska Barbara, Handel zagraniczny Księstwa Warszawskiego. Z badań nad struktura gospodarcza, PWN, Warszawa 1967.

Grochulska Barbara, Kraków w systemie warszawsko-francuskim, w: Kraków w czasach Księstwa Warszawskiego. Materiały sesji naukowej z okazji Dni Krakowa w roku 1988, Towarzystwo Miłośników Historii i Zabytków Krakowa, Kraków 1989, s. 7-19.

Grochulska Barbara, Księstwo Warszawskie, Wiedza Powszechna, Warszawa 1966.

Grochulska Barbara, Lewica wobec Napoleona w świetle „Korespondencji w materiach obraz kraju i narodu rozjaśniających”, w: Francja-Polska. XVIII-XIX w. Studia z dziejów kultury i polityki poświęcone prof. Andrzejowi Zahorskiemu w sześćdziesiąta rocznice urodzin, red. Antoni Mączak, PWN, Warszawa 1983, s. 62-69.

Grochulska Barbara, Małe państwo wielkich nadziei, KAW, Warszawa 1987.

Grynwaser Hipolit, Kwestia agrarna i ruch włościan w Królestwie Polskim w pierwszej połowie XIX w. Studium archiwalne, Kasa im. Mianowskiego - Instytut Popierania Nauki, Warszawa 1935.

Grześkowiak-Krwawicz Anna, o formę rządu, czy o rząd dusz? Publicystyka polityczna Sejmu Czteroletniego, Wydawnictwo IBL, Warszawa 2000.

Grześkowiak-Krwawicz Anna, Regina libertas. Wolność w polskiej myśli politycznej XVIII wieku, Słowo/Obraz/Terytoria, Gdańsk 2006.

Habermas Jürgen, Filozoficzny dyskurs nowoczesności, Universitas, Kraków 2005.

Habermas Jürgen, Obywatelstwo a tożsamość narodowa. Rozważania nad przyszłościa Europy, IFiS PAN, Warszawa 1993.

Handelsman Marceli, Projekt zmiany konstytucji z r. 1812, w: idem, Pod znakiem Napoleona. Studia historyczne, seria II, Zakład Graf. Tow. Akc. S. Orgelbranda S-ów, Warszawa 1913, s. 197-214.

Handelsman Marceli, Z dziejów Księstwa Warszawskiego. Geneza Księstwa i jego statutu, w: idem, Studia historyczne, seria 1, E. Wende, H. Altenberg, Warszawa-Lwów 1911, s. 107-240.

Jedlicki Jerzy, Szlachta, w: Przemiany społeczne w Królestwie Polskim 1815-1864, red. Witold Kula, Janina Leskiewiczowa, Ossolineum, Wrocław 1979, s. 27-56.

Kallas Marian, Dzienniki departamentowe w czasach Księstwa Warszawskiego (1808-1815), „Rocznik Historii Czasopiśmiennictwa Polskiego” 10/1, 1971, s. 5-31.

Kallas Marian, Historia ustroju Polski, PWN, Warszawa 2005.

Kizwalter Tomasz, Kryzys oświecenia a początki konserwatyzmu polskiego, Wydawnictwa UW, Warszawa 1987.

Kizwalter Tomasz, O nowoczesności narodu. Przypadek polski, Semper, Warszawa 1999. Kizwalter Tomasz, W stronę równości, Universitas, Kraków 2014.

Kołłątaj Hugo, Uwagi nad położeniem tej części ziemi polskiej, którą od pokoju tylżyckiego zaczęto zwać Księstwem Warszawskim, Lipsk [Warszawa] 1808.

Kosim Jan, Losy pewnej fortuny. Z dziejów burżuazji warszawskiej w latach 1807-1830, Ossolineum, Wrocław 1972.

Krzymkowski Marek, Status prawny urzędników Księstwa Warszawskiego, Wydział Prawa i Administracji UAM, Poznań 2004. 
Kubis Paweł, Nowoczesność czy tradycja? Konfederacja Generalna Królestwa Polskiego 1812 r., w: Studia nad epoka napoleońską, t. 2, red. Marcin Baranowski, Napoleon V, Oświęcim 2016, s. 150-213.

Lelewel Joachim, Trzy konstytucje polskie 1791, 1807, 1815, w: idem, Dzieła, t. 8, oprac. Józef Dutkiewicz [et al.], PWN, Warszawa 1961.

Leśnodorski Bogusław, Elementy feudalne i burżuazyjne w ustroju i prawie Księstwa Warszawskiego, CPH 3, 1951, s. 304-332.

Leśnodorski Bogusław, U progu nowego stulecia. Księstwo Warszawskie, w: idem, Historia i współczesność, PWN, Warszawa 1967, s. 188-234.

Łepkowski Tadeusz, Polska - narodziny nowoczesnego narodu 1764-1870, Wydawnictwo PTPN, Poznań 2003.

Łukasiewicz Dariusz, Sarmatyzm i Prusy na przełomie XVIII i XIX w., Instytut Historii PAN, Warszawa 2015.

Machalski Edmund, Ludwik Gutakowski. Prezes Rady Stanu i Ministrów, Fundusz Kultury Narodowej im. Marszałka J. Piłsudskiego, Dubno 1938.

Mycielski Maciej, „Miasto ma mieszkańców, wieś obywateli”. Kajetana Koźmiana koncepcje wspólnoty politycznej (do 1830 roku), Wydawnictwo Uniwersytetu Wrocławskiego, Wrocław 2004.

Mycielski Maciej, Rząd Królestwa Polskiego wobec sejmików i zgromadzeń gminnych 1815-1830, Wydawnictwa UW, Warszawa 2010.

Niemcewicz Julian Ursyn, Podróże po Ameryce 1797-1807, z rkp. wyd., wstęp i objaśn. Antonina Wellman-Zalewska, red. Emil Kipa, Ossolineum, Wrocław-Warszawa 1959.

Ossowski Kazimierz, Prasa Księstwa Warszawskiego, Biblioteka Narodowa, Warszawa 2004.

Przygodzki Jacek, Rada Najwyższa Tymczasowa Księstwa Warszawskiego 1813-1815, Wydawnictwo Uniwersytetu Wrocławskiego, Wrocław 2002.

Rembowski Aleksander, Z życia konstytucyjnego Księstwa Warszawskiego, Gebethner i Wolff, Kraków 1900.

Rosner Anna, Sędziowie i urzędnicy sądów pokoju w Księstwie Warszawskim, PH 79, 1988, 4, s. 659-684.

Skałkowski Adam M., O cześć imienia polskiego, Napoleon V, Oświęcim 2015.

Skowronek Jerzy, Aleksander Sapieha. Z magnackiego gniazda do napoleońskiego wywiadu, PWN, Warszawa 1992.

Sobociński Władysław, Historia ustroju i prawa Księstwa Warszawskiego, TNT, Toruń 1970.

Sobociński Władysław, Senkowska-Gluck Monika, Księstwo Warszawskie, w: Historia państwa i prawa Polski, t. 3: Od rozbiorów do uwłaszczenia, red. Juliusz Bardach, Monika Senkowska-Gluck, PWN, Warszawa 1981, s. 66-119.

Sójka-Zielińska Katarzyna, Kodeks Napoleona. Historia i współczesność, Wydawnictwo Prawnicze LexisNexis, Warszawa 2008.

Stankiewicz Zbigniew, Królestwo Polskie 1815-1863, w: Historia państwa i prawa Polski, t. 3: Od rozbiorów do uwłaszczenia, red. Juliusz Bardach, Monika Senkowska-Gluck, PWN, Warszawa 1981, s. 168-468.

Staszic Stanisław, O statystyce Polski: krótki rzut wiadomości potrzebnych tym, którzy ten kraj chca oswobodzić i tym, którzy w nim chcą rządzić, Warszawa 1807. 
Surowiecki Wawrzyniec, Wybór pism, oprac. Joanna Grzywicka, Aleksander Łukaszewicz, PWN, Warszawa 1957.

Szyndler Bartłomiej, Stanisław Nałęcz Małachowski (1736-1809), Wydawnictwo MON, Warszawa 1979.

Tokarz Wacław, Ksiąze Józef jako wychowawca wojska, w: idem, Rozprawy i szkice, t. 2: Militaria, PWN, Warszawa 1959, s. 287-319.

Ustawodawstwo Księstwa Warszawskiego. Akty normatywne władzy najwyższej, t. 2: 18091810, oprac. Wojciech Bartel, Jan Kosim, Władysław Rostocki, PWN, Warszawa 1964.

Willaume Juliusz, Fryderyk August jako książę warszawski (1807-1815), Napoleon V, Oświęcim 2013.

Winiarz Adam, Szkolnictwo Księstwa Warszawskiego i Królestwa Polskiego (1807-1831), Wydawnictwo UMCS, Lublin 2002.

Wybicki Józef, Życie moje oraz wspomnienie o Andrzeju i Konstancji Zamoyskich, wyd. Adam M. Skałkowski, Ossolineum, Wrocław 2005.

Zajewski Władysław, Józef Wybicki, Wiedza Powszechna, Warszawa 1983.

Biogram: Jarosław Czubaty, dr hab., prof. Uniwersytetu Warszawskiego; Instytut Historyczny UW. Obszar zainteresowań: historia społeczna i polityczna schyłku XVIII i pierwszej połowy XIX w.; mentalność polityczna kształtująca się w warunkach braku własnego państwa lub państwa niesuwerennego; historia wojskowa ze szczególnym uwzględnieniem kwestii społecznych związanych z armią; związki życia kulturalnego i kultury z problemami politycznymi epoki, procesami społecznymi i przemianami mentalności; kontakt: j.czubaty@uw.edu.pl. 